\title{
Final Report on the Large Scale Demonstration for the Electrochemical Processing of Hanford and Savannah River Site High-Level Waste Simulants
}

by

D. T. Hobbs

Westinghouse Savannah River Company

Savannah River Site

Aiken, South Carolina 29808

D. Chal

Electrosynthesis Company Incorporated

NY USA

D. Hartsough

Electrosynthesis Company Incorporated

NY USA

D. Genders

Electrosynthesis Company incorporated

NY USA

This paper was prepared in connection with work done under the above contract number with the U.S. Department of Energy. By acceptance of this paper, the publisher and/or recipient acknowledges the U.S. Government's right to retain a nonexclusive, royalty-free license in and to any copyright covering this paper, along with the right to reproduce and to authorize others to reproduce all or part of the copyrighted paper. 


\section{DISCLAIMER}

This report was prepared as an account of work sponsored by an agency of the United States Government. Neither the United States Government nor any agency thereof, nor any of their employees, makes any warranty, express or implied, or assumes any legal liability or responsibility for the accuracy, completeness, or usefulness of any information, apparatus, product, or process disclosed, or represents that its use would not infringe privately owned rights. Reference herein to any specific commercial product, process, or service by trade name, trademark, manufacturer, or otherwise does not necessarily constitute or imply its endorsement, recommendation, or favoring by the United States Government or any agency thereof. The views and opinions of authors expressed herein do not necessarily state or reflect those of the United States Government or any agency thereof.

This report has been reproduced directly from the best available copy.

Available to DOE and DOE contractors from the Office of Scientific and Technical Information, P. O. Box 62, Oak Ridge, TN 37831; prices available from (423) 576-8401.

Available to the public from the National Technical Information Service, U. S. Department of Commerce, 5285 Port Royal Road, Springfield, VA 22161. 
72 Ward Road

Lancaster, NY 14086-9779

TEL: 716-684-0513

FAX: $716-684-0511$

REF. NO.:

6022

TO:

Dr. David Hobbs

COMPANY: Westinghouse Savannah River Company

FROM:

Dr. Norman L. Weinberg

DATE:

March 21, 1997

FAX NO:803-725-4704

TOTAL NUMBER OF PAGES (INCLUDING THIS SHEET): 1

\section{RE: R\&DREPORI}

Dear Dr. Hobbs:

This note is in reference to our R \& D Report to Westinghouse Savannah River Company entitled:

"Electrochemical Processing of Hanford And SRS Waste Simulants Using An ICI FM21-SP Pilot Scale Flow Cell" (Subcontract \#AA82238N; Report Date September 14, 1995).

Electrosynthesis Company, Inc. agrees that you have our permission to release the above document to any party of your choosing or for publication.

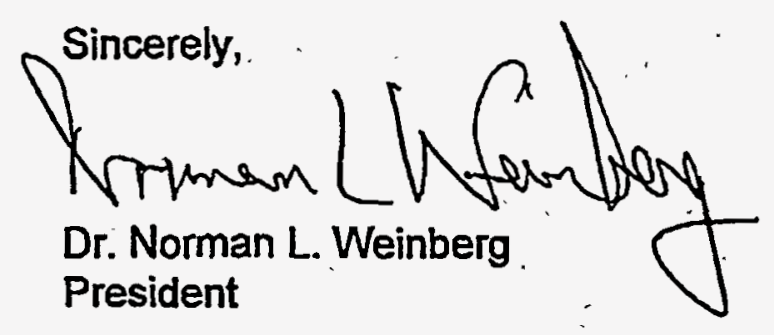




\section{ẂSRC-TR-95-0405}

Keywords: Electrolysis, Alkaline, Salt Solution, Waste Management, Nitrate, Nitrite, Organic

Retention time: permanent

September 21, 1995

TO: $\quad$ S. D. Fink, 773-A<smiles>CC1(C)C2CCCC(C3CCCC3)C1C2</smiles>

FROM: D. T. Hobbs, 773-A

\section{Final Report on the Large Scale Demonstration for the Electrochemical Processing of Hanford and Savannah River Site High-Level Waste Simulants}

(u)

Attached is the final report prepared by the Electrosynthesis Company, Incorporated under contract \#AA82238N investigating the electrochemical destruction of nitrates, nitrites, and organic compounds in an industrial scale electrolyzer with simulated Hanford and Savannah River Site wastes. This report fulfills milestone D.2. of Technical Task Plan SR1-3-20-05, revision 0, "Electrochemical Destruction of Nitrates and'Organics."

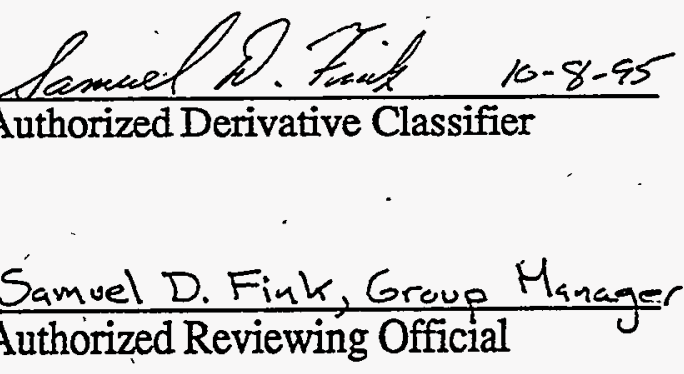

Savannah River Technology Center

Westinghouse Savannah River Company

Aiken, SC 29802 


\title{
$R \& D$ Report
}

\section{"Electrochemical Processing of Hanford and SRS Waste \\ Simulants using an ICI FM21-SP Pilot Scale Flow Cell."}

\author{
Prepared For:
}

Westinghouse Savannah River Company

Savannah River Technology Center

Building 773-A, B-117

Aiken, SC 29808

Attn. Dr. David T. Hobbs

Subcontract \# AA82238N

Prepared By:

Dennis Chai, Research Chemist

Dan Hartsough, Senior Research Chemist

David Genders, Vice-President R\&D

September 14, 1995

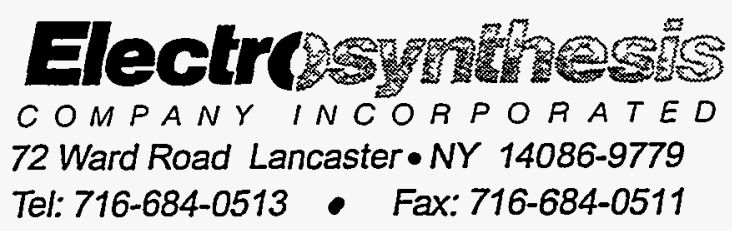




\section{Table of Contents}

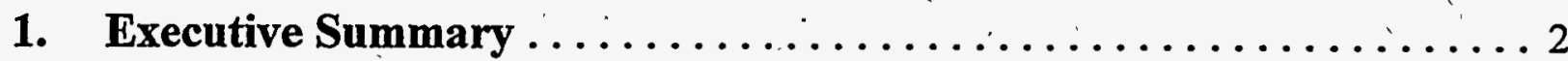

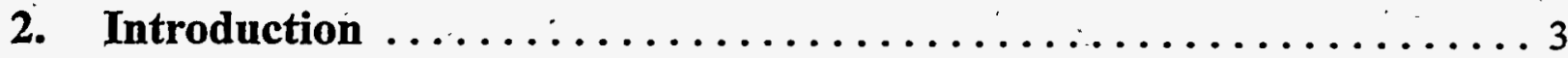

\section{Experimental}

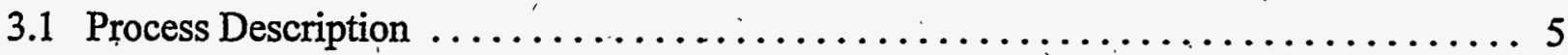

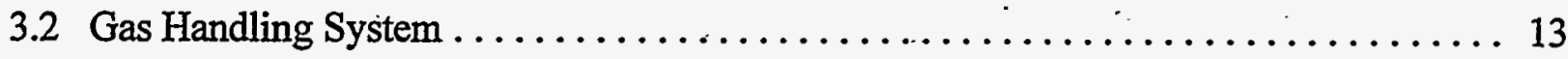

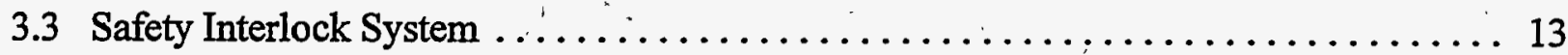

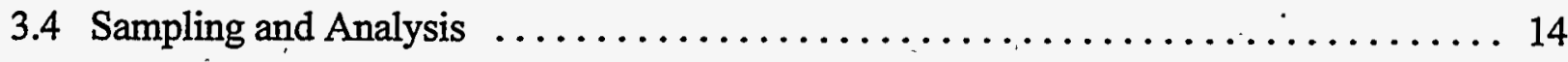

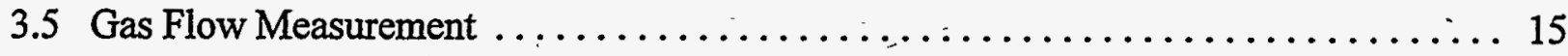

\section{Results and Discussion}

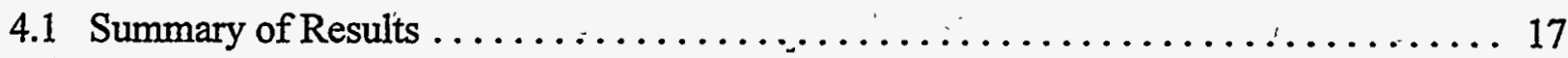

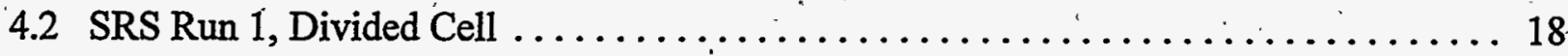

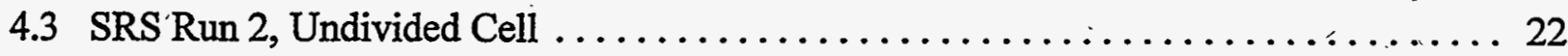

4.4 ,Hanford Run 1, Undivided Cell ................................ 25

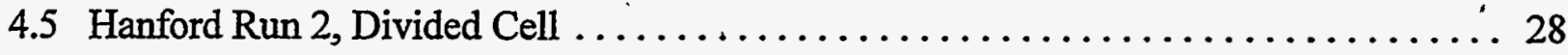

5. Conclusions and Recommendations $\ldots \ldots \ldots \ldots \ldots \ldots \ldots \ldots \ldots \ldots \ldots \ldots$

6. Appendices

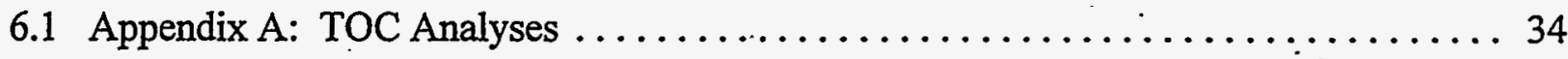

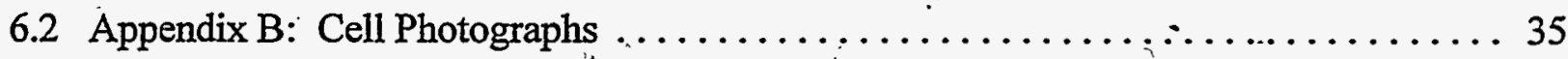




\section{Executive Summary}

Work performed at the Electrosynthesis Company Inc. (ESC) has successfully demonstrated the operation of the ICI FM21-SP commercial scale electrochemical flow cell for the removal of nitrite, nitrate and organic species from SRS and Hanford waste simulants. The FM21-SP cell was operated in a batch mode in both divided and undivided cell configurations for at least 40 hours per experiment or until $50 \%$ of the nitrite, nitrate and organic species were destroyed. The solution concentration of nitrate and nitrite as well as off gas molar flow rates were measured. The cell. performed very well during the four experimental runs. Leak-free assembly and operation was easily accomplished each time. Membrane installation and cell assembly was quick and simple, thus avoiding drying out of the membrane. Hanford waste simulants containing large amounts of suspended solids were pumped through the cell without loss of flow:

The results obtained with the FM21-SP for nitrite and nitrate destruction in the divided cell configuration are similar to those previously obtained by ESC when a laboratory scale cell was used, as well as to results obtained at WSRC when actual low level radioactive waste was tested in the FM01 laboratory cell. Induction periods at the nickel cathodes were observed in divided cell runs with both the SRS and Hanford simulants. These induction periods may be due to the formation and dissolution of chrome (III) hydroxide films on the cathode surface which could inhibit nitrate reduction but allow hydrogen evolution.

In the undivided cell configuration, nitrite and nitrate destruction rates were significantly lower for both simulants tested. The poorer performance of the cell in the undivided mode for nitrite/nitrate destruction could be due again to the formation of chrome (III) hydroxide films, reoxidation of nitrite at the anode, or lower solution alkalinity. High destruction rates of organics were achieved for Hanford simulant in the undivided cell configuration; however, when depleted Hanford simulant with higher $\mathrm{Na}^{+} /$alkalinity content was used as anolyte in the divided cell run, a lower destruction rate was observed. Some destruction of organics was also observed for SRS simulant in undivided cell tests. 


\section{Introduction}

This report details the pilot plant studies of the electrochemical destruction of nitrate, nitrite, and organics from simulated alkaline low-level nuclear waste solutions. The work was conducted at The Electrosynthesis Company, Inc. (ESC) on behalf of Westinghouse Savannah River Company (WSRC) and involved the treatment of Savannah River Site (SRS) and Hanford waste simulants in a full size commercial scale flow cell; the ICI FM21. The low level wastes are formed as a result of treatment processes for high level wastes which remove most of the radioactivity but leave behind large volumes of alkaline low level waste solutions. These solutions contain high levels of nitrate and nitrite which present environmental release hazards as well as organic compounds which pose risks such as the formation of flammable gases during intermediate storage due to radiolytic decomposition of the organics. Organic complexants such as ethylenediamminetetraacetate (EDTA) can also bind radionuclides preventing efficient removal. Electrochemical reduction of nitrite and nitrate results in the formation of nitrogen, ammonia, and nitrous oxide gases which are less harmful to the environment. Electrochemical oxidation of organics reduces the chemical oxygen demand (COD) of the waste and forms carbon dioxide upon complete oxidation of the organics. The destruction of nitrate, nitrite, and organics in the low-level waste could also permit evaporation and recovery of the caustic value of the waste, reducing the volume of the low-level-waste stream for disposal and providing a source of caustic for neutralization of acid waste clean-up solutions.

The electrochemical destruction process was scaled up from previous laboratory scale flow cell work done at ESC 1,2,3 and at WSRC and PNL ${ }^{4,5,6}$. Nearly complete electrochemical reduction

${ }^{1}$ J.D. Genders, "Final Report - Electrochemical Processing of Nitrate Waste Solutions", Electrosynthesis Co., Inc., Report No. WSRC-TR-90-491, May 31, 1990.

2 J.D. Genders, "Phase II Final Report - Electrochemical Processing of Nitrate Waste Solutions", Electrosynthesis Co., Inc., Report No. WSRC-TR-93-090, October 7, 1992.

${ }^{3}$ J.D. Genders, D. Hartsough, and D. T. Hobbs, "Electrochemical Reduction of Nitrate and Nitrites in Alkaline Nuclear Waste Solutions", J. Applied Electrochemistry, publication pending. 
of nitrite and nitrate from SRS simulant to nitrogen, ammonia, or nitrous oxide was demonstrated in laboratory plate and frame flow cells. The performance of various electrode materials was investigated, and the effects of key operating parameters such as temperature, current density, undivided vs. divided cell configuration, and anolyte composition were identified. Nitrite, $\mathrm{N}_{2}, \mathrm{~N}_{2} \mathrm{O}$, and $\mathrm{NH}_{3}$ were the only products identified, formed by the following reactions:

$$
\begin{array}{lll}
\mathrm{NO}_{3}^{-}+\mathrm{H}_{2} \mathrm{O}+2 \mathrm{e}^{-} & \rightarrow & \mathrm{NO}_{2}^{-}+2 \mathrm{OH}^{-} \\
\mathrm{NO}_{2}^{-}+2 \mathrm{H}_{2} \mathrm{O}+3 \mathrm{e}^{-} & \rightarrow & 1 / 2 \mathrm{~N}_{2}+4 \mathrm{OH}^{-} \\
2 \mathrm{NO}_{2}^{-}+3 \mathrm{H}_{2} \mathrm{O}+4 \mathrm{e}^{-} & \rightarrow & \dot{\mathrm{N}}_{2} \mathrm{O}+6 \mathrm{OH}^{-} \\
\mathrm{NO}_{2}^{-}+5 \mathrm{H}_{2} \mathrm{O}+6 \mathrm{e}^{-} & \rightarrow & \mathrm{NH}_{3}+7 \mathrm{OH}^{-}
\end{array}
$$

The electrochemical oxidation of EDTA in the Hanford mix has also been investigated in laboratory flow cells. The overall destruction reaction is:

$$
\mathrm{Na}_{4} \mathrm{EDTA}+12 \mathrm{H}_{2} \mathrm{O} \rightarrow \mathrm{N}_{2}+4 \mathrm{Na}^{+}+36 \mathrm{H}^{+}+\mathrm{CO}_{2}+40 \mathrm{e}^{-}
$$

Other possible anode reactions include the oxidation of hydroxide:

$$
4 \mathrm{OH}^{-} \rightarrow \mathrm{O}_{2}+2 \mathrm{H}_{2} \mathrm{O}+4 \mathrm{e}^{-} \text {, }
$$

and the oxidation of nitrite:

$$
\mathrm{NO}_{2}^{-}+2 \mathrm{OH}^{-} \quad \rightarrow \quad \mathrm{NO}_{3}^{-}+\mathrm{H}_{2} \mathrm{O}+2 \mathrm{e}^{-}
$$

The goal of the present phase was to demonstrate the destruction of nitrate, nitrite, and organics at the pilot scale using the same electrochemical flow cells which could also be used in the final plant. Two tests were performed on the SRS simulant in divided and undivided cells. A sodium hydroxide anolyte was employed in the divided SRS test. These tests investigated the effect of using a cation exchange membrane as a cell divider. Two tests were also conducted with the

\footnotetext{
${ }^{4}$ D.T. Hobbs, "Summary Technical Report on the Electrochemical Treatment of Alkaline Nuclear Wastes (U)". Westinghouse Savannah River Company, Report No. WSRC-TR-94-0287, July 30, 1994.

${ }^{5}$ D.T. Hobbs, "Electrolytic Denitration of Radioactive Savannah River Site Waste (U)". Westinghouse Savannah River Company, Report No. WSRC-TR-95-0176, April 26, 1995.

${ }^{6}$ D.T. Hobbs, "Electrochemical Destruction of Nitrates and Organics FY 1995 Progress Report (U)". Westinghouse Savannah River Company, Savannah River Technology Center, Report No. W.SRC-TR-95-0248, May 30, 1995.
} 
Hanford mix, one undivided and one divided. The divided cell run used a simulated Hanford mix without sodium nitrite or sodium nitrate present as the anolyte. In the plant, the nitrite and nitrate would first be removed from the Hanford mix catholyte; the spent catholyte would then be recycled to the anolyte so that organics destruction could occur at the anode. Each experiment was run for 40 hours or until $50 \%$ reduction in organics and $\mathrm{NO}_{2}^{-}-\mathrm{NO}_{3}{ }^{-}$was achieved and the solution analyzed for nitrate, nitrite, and TOC. The off-gas product composition and flow rate was measured so that the current efficiency for nitrite, nitrate, and organics removal and product distribution as a function of the type of simulant (SRS vs. Hanford) and divided vs. undivided configuration could be determined.

\section{Experimental}

\subsection{Process Description}

All four experimental runs were carried out in an ICI Model FM21SP plate and frame flow cell (Figure 1) with a single pair of planar electrodes. Each electrode has a surface area of $0.21 \mathrm{~m}^{2}$. The membrane to electrode gap is $0.5 \mathrm{~cm}$. For the runs using SRS synthetic. mix, two nickel electrodes were used. For the runs using the synthetic Hanford mix, a platinized titanium anode and a nickel cathode were used. In the divided cell run using a SRS solution, a Nafion ${ }^{\mathrm{R}} 350$ membrane pretreated by soaking in $20 \% \mathrm{NaOH}$ at $80^{\circ} \mathrm{C}$ was used. In the divided cell run using Hanford solution, the used membrane from the SRS solution run was initially used, but was replaced with a new piece of Nafion 350 membrane pretreated by soaking in $1 \mathrm{M} \mathrm{NaOH}$ at $90^{\circ} \mathrm{C}$ for $\sim 2-1 / 2$ hours.

The catholyte and anolyte reservoirs consisted of 50 gallon and 100 gallon custom fabricated fiberglass tanks. The tanks were calibrated before use with water. The solution was circulated using two March Model TE5.5C MD magnetically coupled centrifugal pumps. The impellers in both pumps were machined down and bored out to allow for expansion at elevated temperatures. The flow rates were measured using two EXAKT Model MA200 polysulfone rotameters equipped with 
Model \#MAF3M magnetic floats and Model \#Z31 unlatched limit switches to ensure that a minimum flow was always maintained.

The anolyte and catholyte solutions were heated using two $240 \mathrm{~V}$ x 4000 Watt stainless steel drum heaters. The catholyte heater was connected via relay to an Omega Model \#CN310 digital temperature controller, and the temperature was controlled using a type $\mathrm{J}$ thermocouple inserted via a Teflon thermowell directly into the catholyte solution. The anolyte solution temperature was controlled via the built in controller on the heater. Before each run was started, the solutions were preheated to near the required temperature, using timers connected to the heater relays. The entire pilot plant was contained within two PVC drip trays capable of containing all solutions should a catastrophic failure occur. Placed within each drip tray was an $I^{2} \mathrm{R}$ Model SP-AB spill sensor to detect any leakage that might occur. Power was supplied to the cell by a Rapid Model SCRA 400018 power supply connected via a $1000 \mathrm{~A} / 100 \mathrm{mV}$ shunt to the current manifold. Current readings were taken directly off the shunt using a multimeter. The power supply was connected via relay to the main pilot plant control system.

Electrode potentials were monitored using two Cole Parmer Model HO5990-50 glass body calomel reference electrodes mounted directly in the solution streams. immediately after they exited the cell. A schematic of the pilot plant is shown in Figure 2. 
Figure 1,

FM21-SP Cell

Foating End-Plate

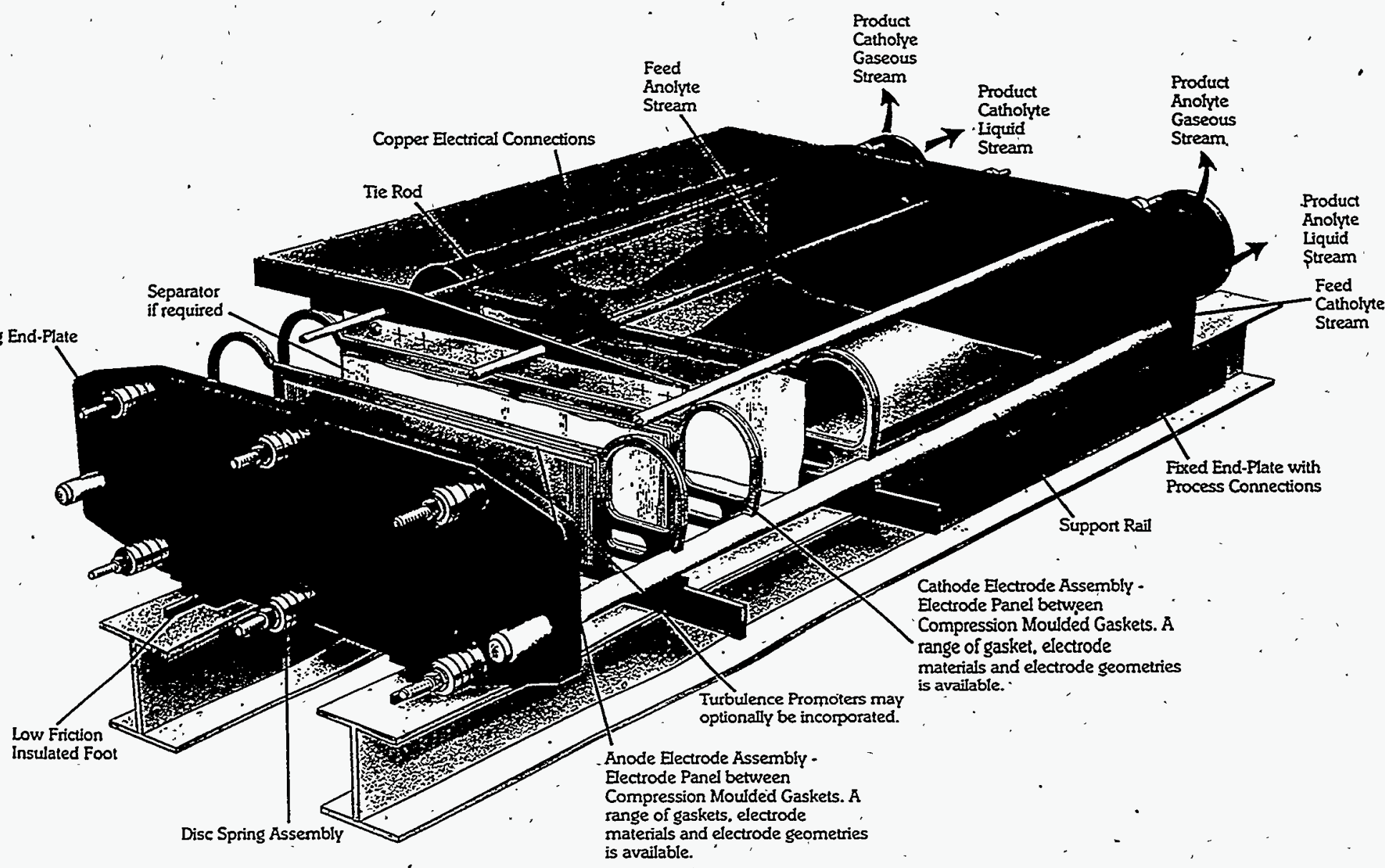

Disc Spring Assembly

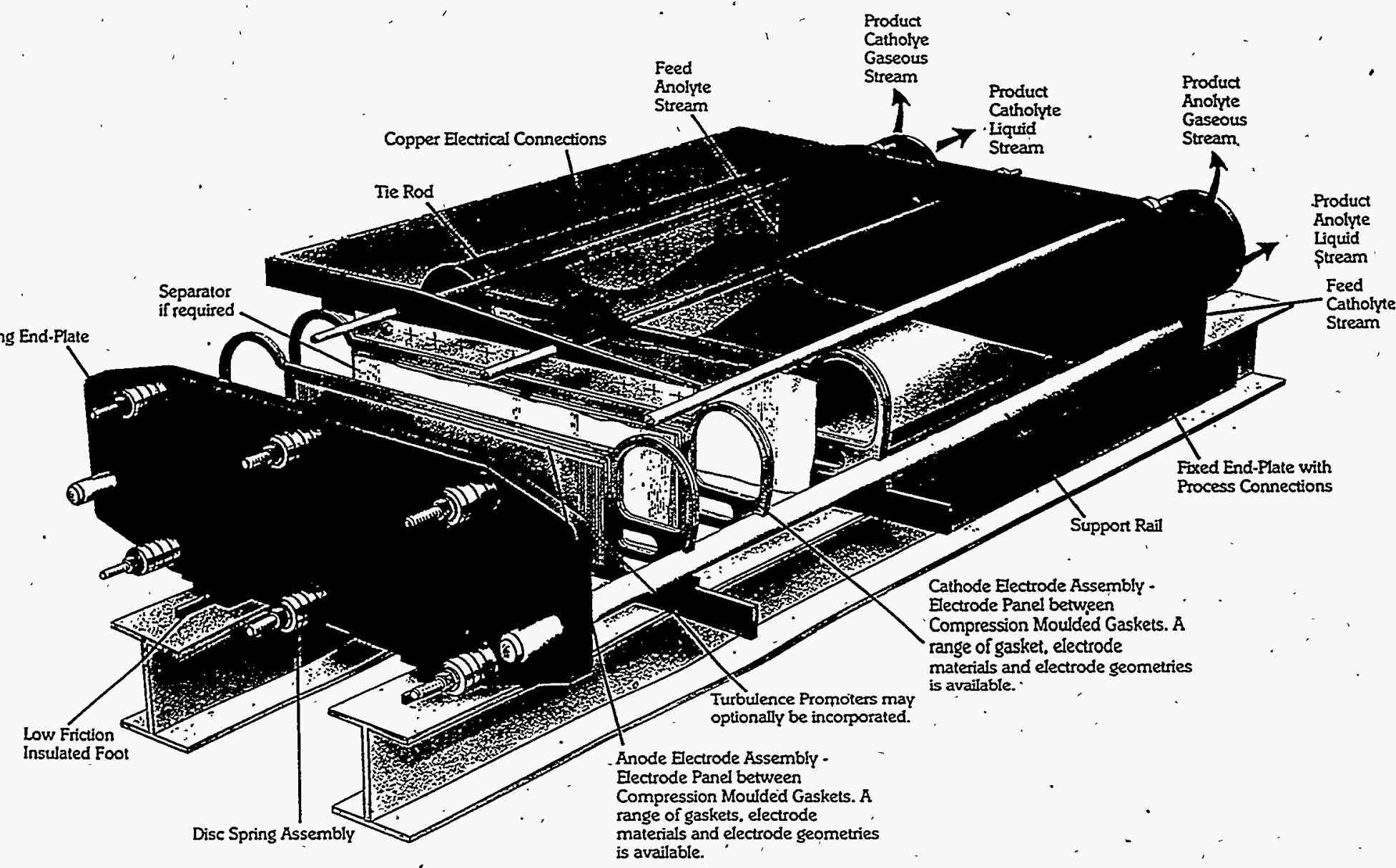


Figure 2: WSRC 3 PILOT PLANT

Page 8

TO EXHAUST FAN

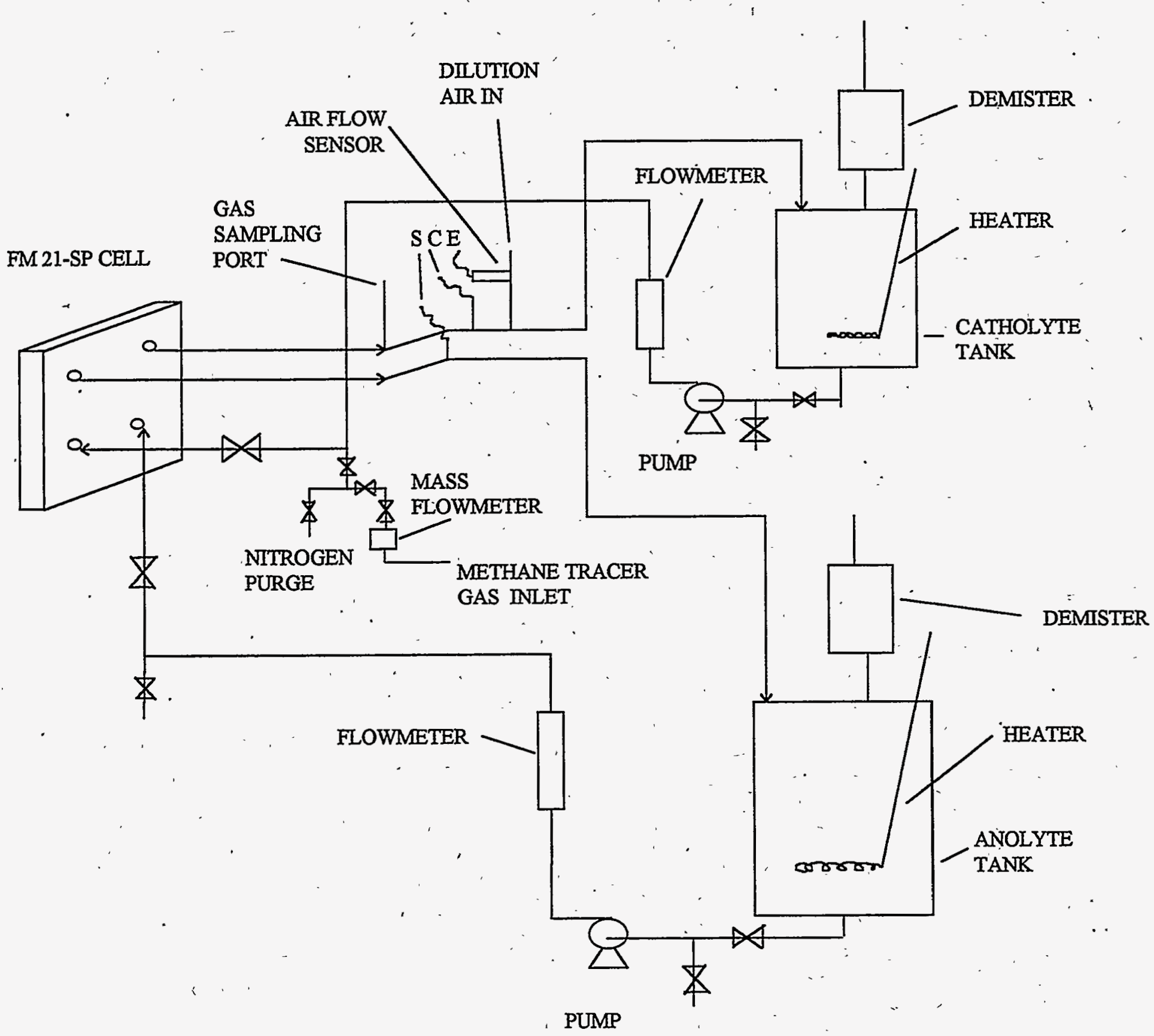


The SRS simulant (see Table 1 for composition) was run in the divided configuration under the following conditions:

$\begin{array}{lcl}\text { Anolyte } & - & 80 \text { gals approx. } 20 \% \mathrm{NaOH} \\ \text { Catholyte } & - & 20 \text { gals SRS simulant } \\ \text { Current Density } & - & 3.5 \mathrm{kA} / \mathrm{m}^{2}(735 \mathrm{~A}) \\ \text { Membrane } & - & \text { Nafion } 350 \\ \text { Circulation.Rate } & - & 4-4.5 \mathrm{gal} / \mathrm{min} . \\ \text { Temperature } & - & 70^{\circ} \mathrm{C} \\ \text { Anode } & - & \text { Nickel } \\ \text { Cathode } & - & \text { Nickel }\end{array}$

The SRS simulant was run in the undivided configuration under the following conditions:

$\begin{array}{lcl}\text { Electrolyte } & - & 15 \text { gal SRS simulant } \\ \text { Anode } & - & \text { Nickel } \\ \text { Cathode } & - & \text { Nickel } \\ \text { Current Density } & - & 3.5 \mathrm{kA} / \mathrm{m}^{2}(735 \mathrm{~A}) \\ \text { Temperature } & - & 70^{\circ} \mathrm{C} \\ \text { Flow rate } & - & 4-4.5 \mathrm{gal} / \mathrm{min} .\end{array}$

The Hanford simulant (see Table 2 for composition) was run in the undivided configuration under the following conditions:

$\begin{array}{lcl}\text { Electrolyte } & - & 15.5 \mathrm{gal} \text { Hanford simulant } \\ \text { Anode } & - & \text { Platinized Titanium } \\ \text { Cathode } & - & \text { Nickel } \\ \text { Current Density } & - & 4.2 \mathrm{kA} / \mathrm{m}^{2}(882 \mathrm{~A}) \\ \text { Temperature } & - & 65^{\circ} \mathrm{C} \\ \text { Circulation Rate } & - & 4-4.5 \mathrm{gal} / \mathrm{min} .\end{array}$

Nalco 2 is a commercial coagulant which was the source of sodium aluminate for the Hanford mix. . It was obtained from Nalco Chemical Company (Oak Brook, II). 
The Hanford simulant was run in the divided configuration under the following conditions:

$\begin{array}{lll}\text { Anode } & - & \text { Platinized Titanium } \\ \text { Cathode } & - & \text { Nickel } \\ \text { Anolyte } & - & 40 \text { gal depleted simulant (see Table } 3 \text { for } \\ & & \text { composition) } \\ \text { Catholyte } & - & 30 \text { gal Hanford simulant } \\ \text { Membrane } & - & \text { Nafion } 350 \\ \text { Circulation Rate } & - & 4-4.5 \mathrm{gal} / \mathrm{min} . \\ \text { Temperature } & - & 65^{\circ} \mathrm{C} \\ \text { Current Density } & - & 4.2 \mathrm{kA} / \mathrm{m}^{2}(882 \mathrm{~A})\end{array}$

TABLE 1

SRS SIMULANT COMPOSITION

\begin{tabular}{|c|c|}
\hline CHEMCAL & CONCENTRATION g/L \\
\hline $\mathrm{NaNO}_{3}$ & 86.7 \\
\hline $\mathrm{NaNO}_{2}$ & 41.4 \\
\hline $\mathrm{Na}_{2} \mathrm{SO}_{4}$ & 19.88 \\
\hline $\mathrm{Na}_{3} \mathrm{PO}_{4} \cdot 12 \mathrm{H}_{2} \mathrm{O}$ & 3.23 \\
\hline $\mathrm{NaCl}$ & 1.29 \\
\hline $\mathrm{NaF}$ & 0.63 \\
\hline $\mathrm{Na}_{2} \mathrm{SiO}_{3}$ & 0.81 \\
\hline $\mathrm{Na}_{2} \mathrm{CrO}_{4} 4 \mathrm{H}_{2} \mathrm{O}$ & 0.77 \\
\hline $\mathrm{NaTPB}(\mathrm{Tetraphenyl} \mathrm{Borate})$ & 0.89 \\
\hline $\mathrm{Na}_{2} \mathrm{CO}_{3}$ & 16.96 \\
\hline $\mathrm{NaOH}$ & 102.8 \\
\hline $\mathrm{HgCl}_{2}$ & 0.0006 \\
\hline $\mathrm{Al}_{\left(\mathrm{NO}_{3}\right)_{3} \cdot 9 \mathrm{H}_{2} \mathrm{O}}$ & 116.29 \\
\hline $\mathrm{RuCl}_{3} \cdot 3 \mathrm{H}_{2} \mathrm{O}$ & 0.0116 \\
\hline
\end{tabular}


TABLE 2

HANFORD SIMULANT COMPOSITION

\begin{tabular}{|c|c|}
\hline CHEMICAL & CONCENTRATION $\mathrm{g} / \mathrm{L}$ \\
\hline $\mathrm{Al}_{2} \mathrm{O}_{3}($ from Nalco 2 ) & 10.9 \\
\hline $\mathrm{Na}_{2} \mathrm{O}$ (from Nalco 2). & 10.0 \\
\hline $\mathrm{Na}_{2} \mathrm{Al}_{2} \mathrm{O}_{4}$ (from Nalco 2) & 17.57 \\
\hline $\mathrm{NaOH}$ (from Nalco 2) & 3.84 \\
\hline $\mathrm{NaOH}$ & 23.5 \\
\hline $\mathrm{Cr}\left(\mathrm{NO}_{3}\right)_{3} \cdot 9 \mathrm{H}_{2} \mathrm{O}$ & 12.62 \\
\hline $\mathrm{Fe}\left(\mathrm{NO}_{3}\right)_{3} \cdot 9 \mathrm{H}_{2} \mathrm{O}$ & 0.808 \\
\hline $\mathrm{Ca}\left(\mathrm{NO}_{3}\right)_{2} 4 \mathrm{H}_{2} \mathrm{O}$ & 0.54 \\
\hline $\mathrm{KNO}_{3}$ & 3.37 \\
\hline $\mathrm{Ni}\left(\mathrm{NO}_{3}\right)_{2} \cdot 6 \mathrm{H}_{2} \mathrm{O}$ & 0.30 \\
\hline $\mathrm{ZnCl}_{2}$ & 0.017 \\
\hline $\mathrm{Cs} \mathrm{NO}_{3}$ & 0.0084 \\
\hline $\mathrm{Sr}\left(\mathrm{NO}_{3}\right)_{2}$ & 0.000625 \\
\hline $\mathrm{NaNO}_{3}$ & 52.187 \\
\hline $\mathrm{NaNO}_{2}$ & 63.0 \\
\hline $\mathrm{Na}_{2} \mathrm{CO}_{3}$ & 22.2 \\
\hline $\mathrm{Na}_{3} \mathrm{PO}_{4} \cdot 12 \mathrm{H}_{2} \mathrm{O}$ & 10.24 \\
\hline $\mathrm{Na}_{2} \mathrm{SO}_{4}$ & 2.365 \\
\hline $\mathrm{NaCL}$ & 5.19 \\
\hline $\mathrm{NaF}$ & 0.265 \\
\hline $\mathrm{Na}_{4}$ EDTA & 21.2 \\
\hline
\end{tabular}


TABLE 3

HANFORD DEPLETED SIMULANT COMPOSITION

\begin{tabular}{|c|c|}
\hline CHEMTCAL & CONCENTRATION $(\mathrm{g} / \mathrm{L})$ \\
\hline $\mathrm{Al}_{2} \mathrm{O}_{2}($ from Nalco 2$)$ & 10.9 \\
\hline $\mathrm{Na}_{2} \mathrm{O}($ from Nalco 2$)$ & 10.0 \\
\hline $\mathrm{NaAl}_{2} \mathrm{O}_{4}($ from Nalco 2$)$ & 17.57 \\
\hline $\mathrm{NaOH}($ from Nalco 2$)$ & 3.84 \\
\hline $\mathrm{NaOH}$ & $\sim 13 \mathrm{Molar}$ \\
\hline $\mathrm{Cr}\left(\mathrm{NO}_{3}\right)_{3} \cdot 9 \mathrm{H}_{2} \mathrm{O}$ & 12.62 \\
\hline $\mathrm{Fe}\left(\mathrm{NO}_{3}\right)_{3} \cdot 9 \mathrm{H}_{2} \mathrm{O}$ & 0.808 \\
\hline $\mathrm{Ca}\left(\mathrm{NO}_{3}\right)_{2} \cdot 9 \mathrm{H}_{2} \mathrm{O}$ & 0.54 \\
\hline $\mathrm{Ni}\left(\mathrm{NO}_{3}\right)_{2} \cdot 6 \mathrm{H}_{2} \mathrm{O}$ & 0.30 \\
\hline $\mathrm{ZnCl}_{2}$ & .017 \\
\hline $\mathrm{CsNO}_{3}$ & $.00,84$ \\
\hline $\mathrm{Na}_{2} \mathrm{CO}_{3}$ & 22.2 \\
\hline $\mathrm{Na}_{3} \mathrm{PO}_{4} \cdot 12 \mathrm{H}_{2} \mathrm{O}$ & 10.24 \\
\hline $\mathrm{Na}_{2} \mathrm{SO}_{4}$ & 2.36 \\
\hline $\mathrm{NaCl}$ & 5.19 \\
\hline $\mathrm{NaF}$ & 0.265 \\
\hline $\mathrm{Na}_{4} \mathrm{EDTA}$ & 21.2 \\
\hline${\mathrm{Sr}\left(\mathrm{NO}_{3}\right)_{2}}$ & .000625 \\
\hline
\end{tabular}




\subsection{Gas Handling System}

In the divided cell configuration, the oxidation gas products (mainly $\mathrm{O}_{2}$ and $\mathrm{CO}_{2}$ ) were first passed though a condenser/demister consisting of 304 stainless steel woven fabric wound around stainless steel cooling coils and all contained in a 5 gal polyethylene drum, then vented to the atmosphere.

In the divided as well as undivided cell configuration the reduction gas products as well as the mixed gas products (oxidation and reduction) were first diluted to safe levels by the.introduction of dilution air into the gas stream shortly after it exited the cell. This was accomplished using a Nalge Model 71320-0075 explosion proof lab blower. The flow of dilution air was continuously monitored using an Omega Model FST320 thermal dispersion flow switch mounted directly in the dilution air inlet pipe. The flow switch was connected to an Omega Model LVCN140 controller and powered by a Lambda Model \#LLS5120 power supply. The diluted gas products were then drawn through a condenser/demister similar to that described above and then through the blower to the outside atmosphere. The flow of gases through the blower was also continually monitored by measuring the change in pressure across the blower using a water manometer and an $I^{2} R$ Thermowatch capacitance controller model L7-11005A coupled with a sensing head attached directly to the manometer.

The actual flow of dilution air was also measured periodically using a Kurtz Model 444 air velocity meter:

\subsection{Safety Interlock System}

The pilot plant was controlled by an ESC Boss 700 series electrochemical,process control system. This monitored the process and was designed to initiate the safety interlock system in the event of an unsafe condition. The unsafe conditions are listed below: 


$\begin{array}{lcl}\text { Anolyte Flow } & - & \text { Low } \\ \text { Catholyte Flow } & - & \text { Low } \\ \text { Cell Spill Sensor } & - & \text { Activated } \\ \text { Tank Spill Sensor } & - & \text { Activated } \\ \text { Dilution Airflow } & - & \text { Low } \\ \text { AP Across Lab Blower } & - & \text { Low } \\ \text { Cell Voltage } & - & \text { High }\end{array}$

In the event that any of these conditions occurred, then the power supply was automatically shut off and a nitrogen purge automatically introduced via an activated solenoid valve into the cell. In addition, the automatic shutdown sequence could be activated manually.

\subsection{Sampling And Analysis}

Solution samples were taken directly from the recirculating tanks using a $50 \mathrm{~mL}$ syringe with an extended tip and stored in polyethylene sample bottles. The samples were analyzed for alkalinity using the standard acid-base titration with $1.0 \mathrm{M} \mathrm{HCl}$ and phenolphthalein indicator. The samples were analyzed for nitrate, nitrite and sulfate species using a Dionex DX500 Ion Chromatograph equipped with an automated sampler and controlled using the Peaknet ${ }^{\mathrm{TM}}$ software system. 'The nitrite, nitrate and sulfate species were separated and quantified on an IonPac AS4A-SC 4mm column with an IonPac AG 4A-SC 4mm guard column. The eluent consisted of $0.0018 \mathrm{M} \mathrm{Na}_{2} \mathrm{CO}_{3}$ $+0.0017 \mathrm{M} \mathrm{NaHCO}_{3}$ at a flow rate of $2 \mathrm{ml} / \mathrm{min}$. The eluent was pumped with a Model GP40 gradient pump and the species detected on a Model CD20 conductivity detector. Three separate standards were used to calibrate the ion chromatograph each time a set of samples was analyzed. The samples and standards were diluted 1:5000 before being placed in the autosampler. Solution samples for organic analysis were sent to Galbraith Laboratories (Knoxville, TN) for total organic carbon and total inorganic carbon analysis.

Gas samples were taken from a Teflon "standpipe" located on an incline at the cell catholyte exit port using a $0.5 \mathrm{~mL}$ gas tight syringe and analyzed on a Gow Mac gas chromatograph equipped with a series 550P thermal conductivity detector and Hewlett Packard \#3396A integrater. Ammonia 
and nitrous oxide were separated and quantified on a Chromasorb 103 column modified with 10\% Versamide $900 / 8 \% \mathrm{KOH}$, using helium as the carrier gas at a column pressure of $\sim 40 \mathrm{psi}$. Oxygen, nitrogen and methane were separated and quantified on a Molecular Sieve 5A 60/80 10ft column also using helium at $\sim 40$ psi column pressure. Hydrogen was also separated and quantified on the molecular sieve column but using argon as the carrier gas also at a pressure of $\sim 40 \mathrm{psi}$. The ratio and quantity of gases present was determined by using a external standard gas mixture (Scott Specialty Gases, Certified Master gas, $\pm 2 \%$ ) with the following composition:

\begin{tabular}{|c|c|}
\hline $\mathrm{NH}_{3}$. & 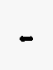 \\
\hline $\mathrm{CH}_{4}$ & - \\
\hline $\begin{array}{l}\mathrm{N}_{2} \\
\mathrm{H}_{2}\end{array}$ & - \\
\hline
\end{tabular}

A separate gas mixture containing $10.1 \% \mathrm{~N}_{2} \mathrm{O}$ in helium was used to calibrate the $\mathrm{GC}$ for $\mathrm{N}_{2} \mathrm{O}$ as $\mathrm{N}_{2} \mathrm{O}$ could not be safely blended with the first calibration gas mix. Methane was used as a "tracer" gas to quantify the total flow of product gases exiting the cell.

\subsection{Gas Flow Measurement}

Total off-gas flow rate was determined by using methane as a tracer gas. Methane was injected into the solution inlet using a mass flowmeter (Sierra Top Trak ${ }^{\mathrm{TM}} 820$ Series Model No. 822-2-OVI-PS-V1-T5, 0 - I LPM flow range, $\pm 2 \%$ accuracy) to measure the volumetric flow rate. The percentage of methane in the off-gas was then determined by GC. Since the methane flow rate and percentage of off-gas were known, the total gas flow rate could be determined, and the flow rate of component gases in moles per unit time could be determined in order to calculate current efficiencies for gaseous reaction products. The accuracy of the methane tracer gas technique was tested by injecting methane at known flow rates into dilute, pure $\mathrm{NaOH}(0.3 \mathrm{M})$ in the undivided FM21 cell (Ni anode and cathode). The caustic was electrolyzed at 1,2 , and $3.5 \mathrm{kA} \mathrm{m}^{-2}$ with methane injection and the off-gas composition analyzed by GC. The only possible reaction is:

$$
2 \mathrm{H}_{2} \mathrm{O} \quad \rightarrow \quad 2 \mathrm{H}_{2}+\mathrm{O}_{2}
$$




\section{The Electrosynthesis Co., Inc.}

Therefore, at a given current, both the volumetric flow rate of off-gas and the composition are known. Methane injected into the cell at a known flow rate should then comprise a known percentage of the off-gas at each current. Figure 3 gives the percentage of methane found in the offgas at each current vs. the theoretical percentage of methane in the off-gas. The theoretical percentage of methane is corrected for room temperature. The figure shows excellent agreement between the theory amount of methane produced and that actually found. This indicates that the tracer gas technique will accurately measure total off-gas flow rates.

Figure 3

FM21 Cell Methane Trácer Gas Test

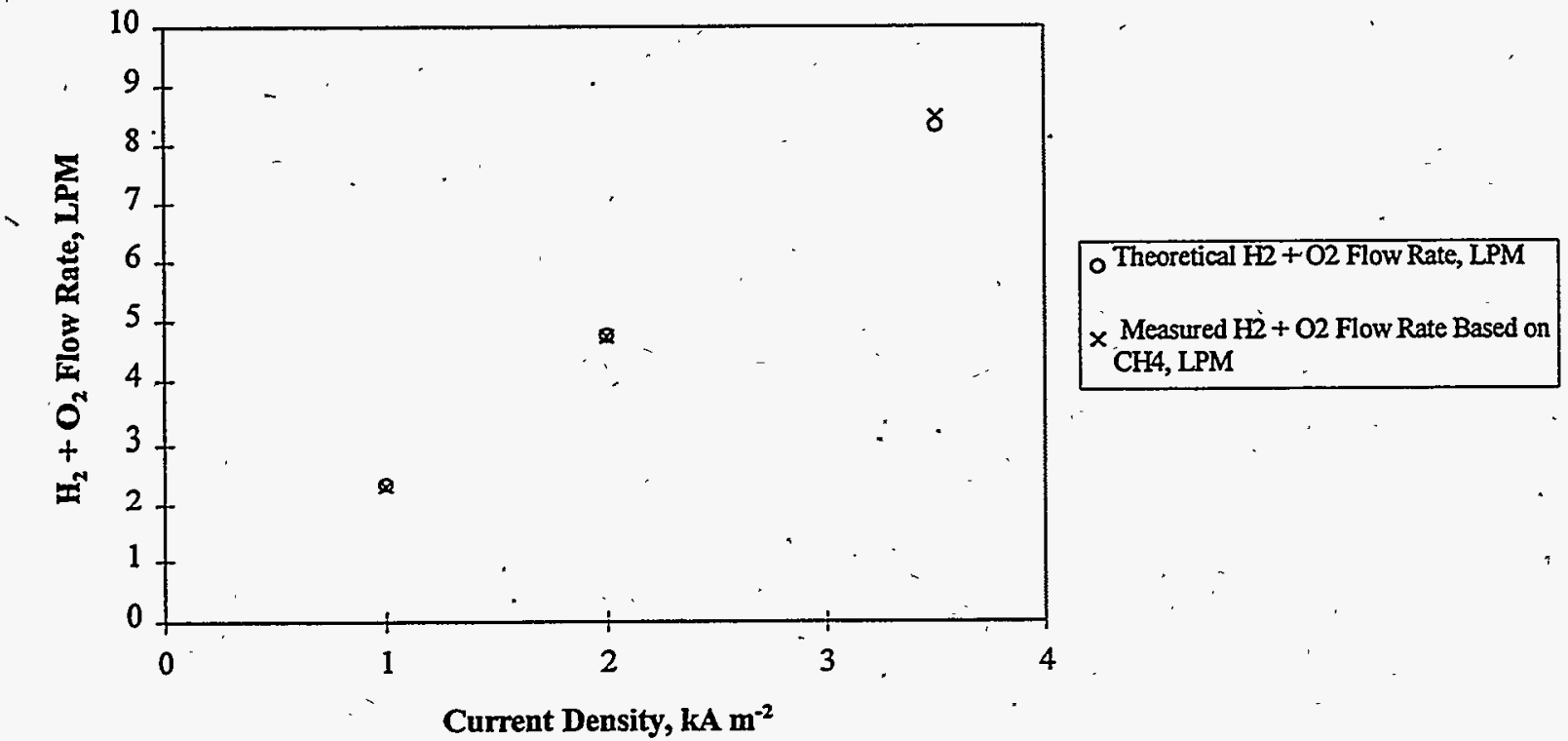




\section{Results and Discussion}

\subsection{Summary of Results}

Table 4 summarizes the voltages, solution volumes, and solution composition at the start and end of each of the four experiments.

\section{Table 4}

\section{Summary of Results}

\begin{tabular}{|c|c|c|c|c|}
\hline & $\begin{array}{c}\text { SRS Soln, } \\
\text { Divided Cell }\end{array}$ & $\begin{array}{c}\text { SRS Soln, } \\
\text { Undivided Cell }\end{array}$ & $\begin{array}{c}\text { Hanford Soln, } \\
\text { Undivided Cell }\end{array}$ & $\begin{array}{c}\text { Hanford Soln, } \\
\text { Divided Cell }\end{array}$ \\
\hline Cell Voltage(V) & $4.0-4.5$ & $3.3-3.4$ & $4.4-6.9$ & $7.1-4.9$ \\
\hline Anode vs SCE (V) & $0.33-32$ & $2.33-2.30$ & $0.53-0.68$ & $0.51-0.40$ \\
\hline Cathode vs SCE (V) & $1.10-1: 33$ & $1.00-1.16$ & {$[4.40-6.20] \dagger$} & $1.45-1.36$ \\
\hline Run Time (Hrs) & 49.3 & 40 & .40 .2 & 38.2 \\
\hline Charge Passed (coul) & $1.31 \mathrm{E} 8$ & $1.06 \mathrm{E} 8$ & $1.28 \mathrm{E} 8$ & $1.21 \mathrm{E} 8$ \\
\hline Initial Vol Cath (Gal) & 20 & 15 & 15.5 & 30 \\
\hline Final Vol Cath (Gal) & 20.5 & 14.5 & 15 & 30 \\
\hline Initial Vol Anolyte (Gal) & 80 & - & - & 40 \\
\hline Final Vol Anolyte (Gal) & - & - & - & 37.5 \\
\hline Initial Nitrite (M) & 0.53 & 0.53 & 0.74 & 0.75 \\
\hline Final Nitrite (M) & 0.34 & 0.36 & 0 & 0.29 \\
\hline Initial Nitrate (M) & 1.99 & 2.04 & 0.74 & 0.77 \\
\hline Final Nitrate (M) & 0.73 & 2.08 & 1.67 & 0.40 \\
\hline Initial TOC (mg/L) & - & $750^{*}$ & 7600 & $.7600^{*}$ \\
\hline Final TOC (mg/L) & - & 460 & 1750 & 5904 \\
\hline
\end{tabular}

Theoretical Amount

$\dagger \quad$ Note that potentials measured for the electrodes are not compensated for iR. Clearly this cathode potential includes almost all of the cell iR. 


\subsection{SRS Run 1 - Divided Cell}

For this run, the catholyte was 20 gallons of the SRS mix and the anolyte was 80 gallons of $8 \mathrm{M} \mathrm{NaOH}$. The cell was separated by Nafion ${ }^{\circledR} 350$ cation exchange membrane which was pretreated by soaking in $20 \% \mathrm{NaOH}$ at a temperature of $80^{\circ} \mathrm{C}$ for three hours. Both electrodes were nickel; and the cell was operated at a current density of $3.5 \mathrm{kA} \mathrm{m}^{-2}(735 \mathrm{~A})$ and a temperature of 70 ${ }^{\circ} \mathrm{C}$ for a total run length of 49.1 hours. Anolyte and catholyte flows were $4.5 \mathrm{gpm}$. Deionized water was periodically added to the catholyte to make the volume back up to approximately 20 gallons.

After 49.1 hours of electrolysis, $56 \%$ of the combined $\mathrm{NO}_{3}^{-}+\mathrm{NO}_{2}^{-}$was removed from solution, and the overall current efficiency was $60 \%$ assuming ammonia as the only product. This assumption was made because ammonia was the only gaseous nitrate reduction product seen in the GC analyses. Figure 4 shows the solution analyses from the catholyte. The figure shows an induction period for roughly the first 20 hours of electrolysis where little nitrate/nitrite destruction occurred. No ammonia was seen in the off-gas during this period (Figure 5 ), and the production rate and current efficiency for hydrogen are high.(Figures 6-7). Some ammonia may have formed in solution during this period but not degassed at the sample point because its concentration was too low to exceed its solubility in the solution. During this period, the SRS solution was yellow and clear, and the cell voltage was $4.0-4.5$ Volts. '.

Figure 4

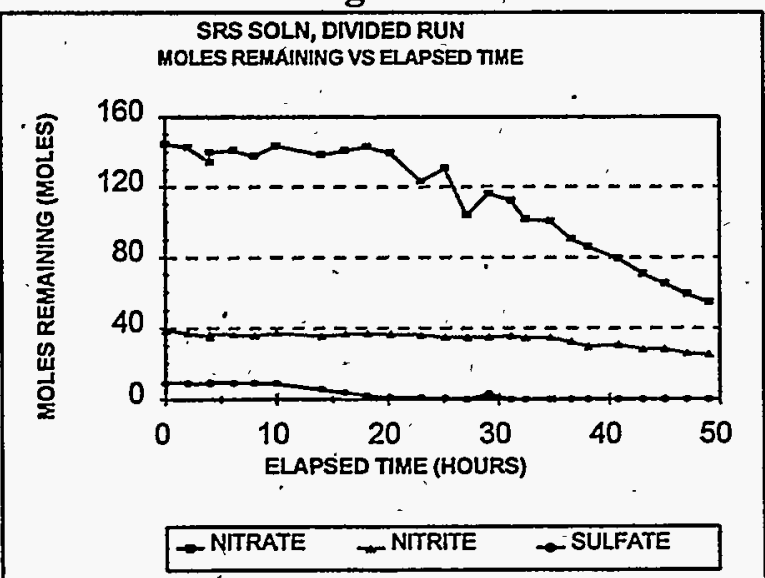

Figure 5

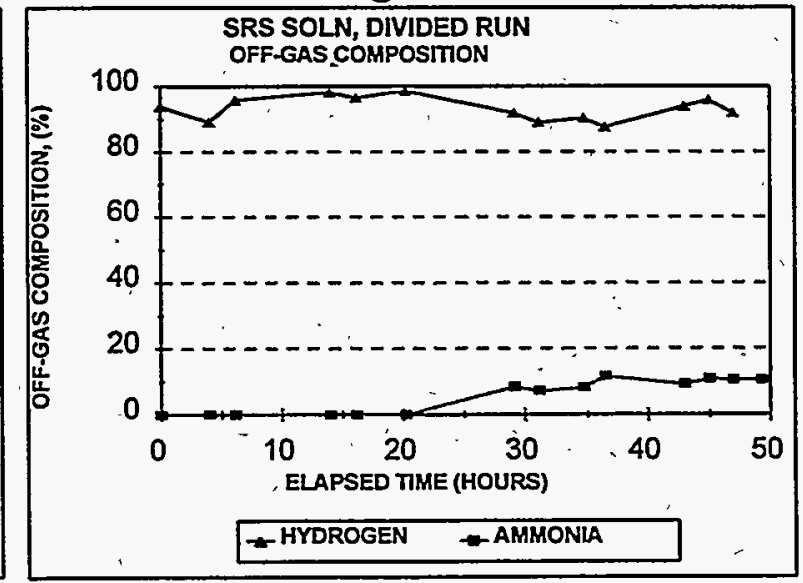


Figure 6

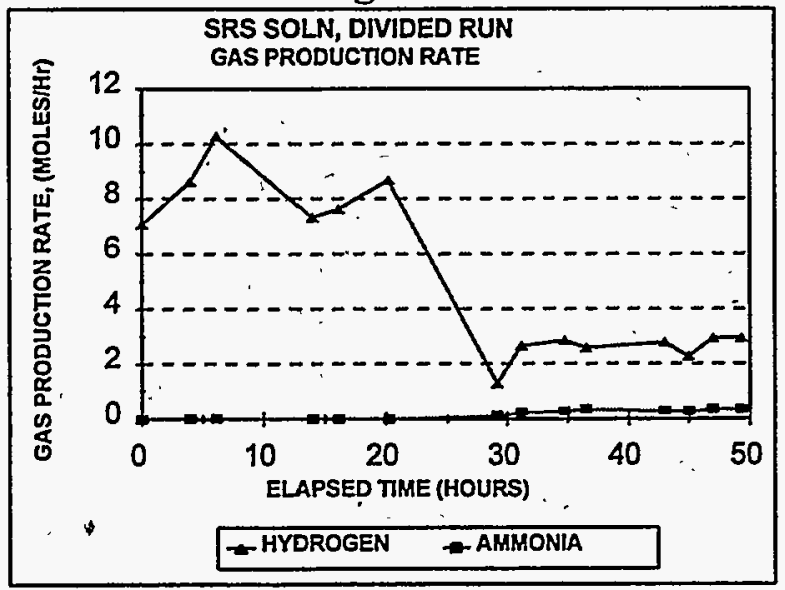

Figure 7

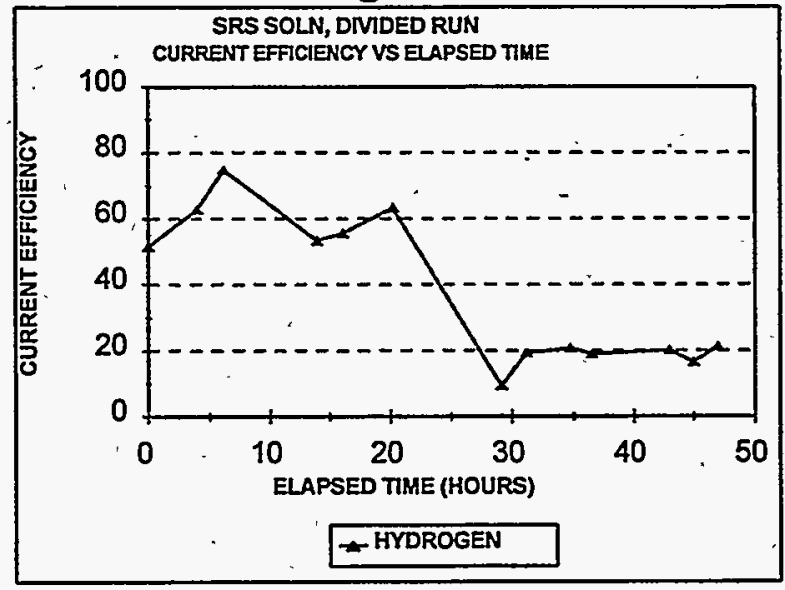

After about 20 hours, the performance of the cell changed dramatically. Nitrate began to be reduced at an appreciable rate, and the hydrogen production rate and current efficiency dropped markedly. The solution color changed from yellow to grayish-green, and solids appeared in solution. These solids are mainly sodium sulfate, since the IC analyses indicated that sulfate disappeared from solution at about this time and IC analysis of the solids dissolved in water showed sulfate as the main peak. Sodium sulfate is probably the least soluble of the salts present in the mix and would therefore be the first to precipitate when the sodium concentration increased due to transport of sodium from the anolyte to catholyte. The hydrogen production rate and hydrogen current efficiency remained low for the remainder of the run.

Overall 271 moles of hydrogen were produced and 13.5 moles of nitrite plus 90.1 moles of nitrate were consumed. If we assume that nitrate/nitrite were reduced to form ammonia only, then the hydrogen and ammonia formation would require 1344 moles of electrons; 1353 moles of electrons were actually passed. Thus virtually all of the current may be accounted for by hydrogen production and ammonia production. However, only 5.6 moles of ammonia gas were actually accounted for by GC analyses and 2.3 moles ammonia were found in solution. If ammonia is the only product, it must have degassed from solution at the catholyte tank rather than at the sample point at the cell outlet. In order to lower the concentration of hydrogen below the explosive limit, 
a high dilution air flow was used at the tank which made the analysis of reduction products coming off the tank impossible.

The rate for nitrate plus nitrite destruction was $1.26 \times 10^{-6} \mathrm{moles} /$ coulomb from twenty hours to the end of the experiment. The rate of destruction in the divided Hanford mix run was $1.48 \times 10^{-6}$ moles/coulomb (see Section 4.5) after the induction period and the rate of destruction in the ETF concentrate was between 1.1 and $1.5 \times 10^{-6}$ moles/coulomb (Runs ED-11 - ED-15) when a divided cell with a nickel cathode was used. ${ }^{7}$ The rate of destruction in laboratory scale work at ESC with the SRS mix (Run \#223-51, divided cell, nickel cathode) was $1.0 \times 10^{-6}$ moles/coulomb after the induction period. ${ }^{8}$ Thus the rate of destruction at nickel after the induction period is similar in the FM21 cell with both the Hanford and SRS mix to that seen at ESC when a laboratory scale cell was used with the SRS mix and also is similar to work at WSRC where actual low level radioactive waste was tested in the FM01 cell. This demonstrates a successful scaleup of the process to the commercial scale.

Induction periods with nickel cathodes have been observed in previous divided laboratory scale flow cell experiments with the SRS mix. This period was only about I hour in Run 223-51. 9 When the solution volume was increased (Run 223-68), the induction period lasted for the entire run (50 hours). ${ }^{10}$ These experiments were run at a higher current density $\left(5 \mathrm{kA} \cdot \mathrm{m}^{-2}\right)$ and with a sulfuric acid anolyte. Color changes were noted in the first experiment; after the induction period, the SRS mix changed from yellow to pale green, suggesting the reduction of $\mathrm{Cr}^{6+}$ to $\mathrm{Cr}^{3+}$. No such color change was observed in the second experiment. No induction period at nickel was seen in work at WSRC with the ETF concentrate (Runs ED-11, ED-12, ED-13). ${ }^{11}$. These tests were conducted at 5

\footnotetext{
${ }^{7}$ D.T. Hobbs, Report No. WSRC-TR-95-0176, April 26, 1995. op. cit'

${ }^{8}$ J.D. Genders, "Phașe II Final Report", 37-38.. op. cit.

9J.D. Genders, "Phase II Final Report", 37-38. op. cit.

${ }^{10}$ J.D. Genders, "Phase II Final Report"; 33-34, 51-52. op. cit.

${ }^{11}$ D.T. Hobbs, Report No. WSRC-TR-95-0176, April 26, 1995. op. cit.
} 
$\mathrm{kA} \mathrm{m}^{-2}, 40^{\circ} \mathrm{C}$, and used a sodium hydroxide anolyte. The ETF concentrate did not contain chromate. The literature indicates that chromate in base can form $\mathrm{Cr}(\mathrm{OH})_{3}$ films on platinum, gold, and iron cathodes which hinder electron transfer across the film and prevent large molecules such as $\mathrm{ClO}$; $\mathrm{Fe}(\mathrm{CN})_{6}{ }^{3-}$, and chromate from reaching the active electrode surface. The films are, however, permeable to hydroxide and hydrogen, thus allowing water electrolysis and hydrogen evolution to occur. ${ }^{12,13,14}$ The color change seen in the present pilot plant run and in Run 223-51 suggests that breakdown of the film occurs allowing further reduction of chromate as well as reduction of nitrate/nitrite. The breakdown of the film would then end the induction period. Reduction of nitrate at a nickel cathode is said to be inhibited by chromate which forms chromium hydroxide films, whereas chromate is said to be reduced to soluble chromite $\left(\mathrm{CrO}_{2}^{-}\right)$at lead cathodes thus avoiding film formation and inhibition of nitrate reduction. ${ }^{15}$ These findings are supported by our Phase II work where lead cathodes did not show any induction periods and gave good, reproducible current efficiencies for nitrate/nitrite reduction in 5, 50, and 1000 hour divided flow cell tests. It has also been shown that the addition of chromate to base lowers the normally high hydrogen overpotential of a lead cathode; however, the inhibition of the reduction of larger molecules was not investigated. ${ }^{16}$

The addition of alkali to $\mathrm{Cr}^{3+}$ salts precipitates $\mathrm{Cr}(\mathrm{OH})_{3} \cdot \mathrm{xH}_{2} \mathrm{O}$ in a gel form. The freshly prepared precipitate is amphoteric, dissolving in acid to form $\mathrm{Cr}^{3+}$ salts and in base to form chromites. However, the precipitate becomes less readily dissolved by alkali on standing for prolonged periods of time. ${ }^{17}$ Thus the behavior of the chromium hydroxide films is complex and

${ }^{12}$ G. Lindbergh and D. Simonsson, J. Electrochem. Soc., 137, 3094 (1990).

${ }^{13} \mathrm{G}$. Lindbergh and D. Simonsson, Electrochim. Acta., 36, 1985 (1991). .

${ }^{14}$ A. Cornell, G. Lind̄bergh and D. Simonsson, Electrochim. Acta., 37, 1873 . (1992).

${ }^{15}$ D.T. Hobbs, Report No. WSRC-TR-95-0248, May 30, 1995. op. cit.

${ }^{16} \mathrm{G}$. Lindbergh and D. Simonsson, Extended Abstract No. 1176 presented at the 172 nd Electrochemical Society Meeting, Honolulu, Hawaii (1987).

${ }^{17}$ H. Remy, "Treatise on Inorganic Chemistry", Vol. II, 135-136 (1956). 
requires more fundamental study. One option could be to simply remove chromate from the solution in a pretreatment step. An electrochemical procedure using high surface area electrodes for chromate removal from alkaline solutions has been described. ${ }^{18}$ However, nearly complete removal of chromate would have to be achieved as even low concentrations of chromate are thought to form the film.

Cell inspection after the run revealed no signs of precipitates in the membrane. The anode was discolored brown and the cathode was discolored grey. No precipitates could be scraped off the electrodes for analysis.' The end catholyte was green in color with white solids precipitated and foam at the top. The catholyte had a strong ammonia odor. Photographs of the cell are included in Appendix B.

The hydroxide concentration increased from $1.9 \mathrm{M}$ to $14,9 \mathrm{M}$ during the run. The nitrite/nitrate destruction would have formed 906 moles of hydroxide, assuming ammonia as the only product, and would have required 802 moles of electrons. The remaining current (543 moles of electrons) must have gone into hydrogen formation and therefore formed 543 moles of hydroxide. The total increase in catholyte hydroxide found by titration was 979 moles, therefore the current efficiency for hydroxide formation in the 'catholyte is $68 \%$. The inefficiency is likely due to the back-migration of $\mathrm{OH}^{-}$across the membrane.

\subsection{SRS Run 2 - Undivided Cell}

The cell was put together using the reverse (unused) side of both nickel electrodes from the first run. They were first both degreased with acetone and rinsed with water before being inserted into the cell. The cell was run for a total of 40 hours over a 5 day period. The temperature was maintained at or close to $70^{\circ} \mathrm{C}$ for the entire run. Deionized water was added periodically to maintain a constant electrolyte volume since water vapor was continually being lost through the gas

\footnotetext{
${ }^{18} \mathrm{M}$. Lipsztajn, "Electrochemical Removal of Chromium from Chlorate Solutions", US Patent No. $4,834,848$ (1989).
} 
venting system. Periodic tests of the water.vapor (via a condensate trap attached to the blower housing) for $\mathrm{pH}$ indicated that only a minute amount of caustic mist was slipping past the demister. The solution color remained yellow throughout the entire run, indicating the continued presence of chrome(VI) species. Figures 8-10 show the $\mathrm{NO}_{2}{ }^{-} / \mathrm{NO}_{3}{ }^{-}$destruction, off gas composition and gas current efficiencies obtained during the run.

\section{Figure 8}

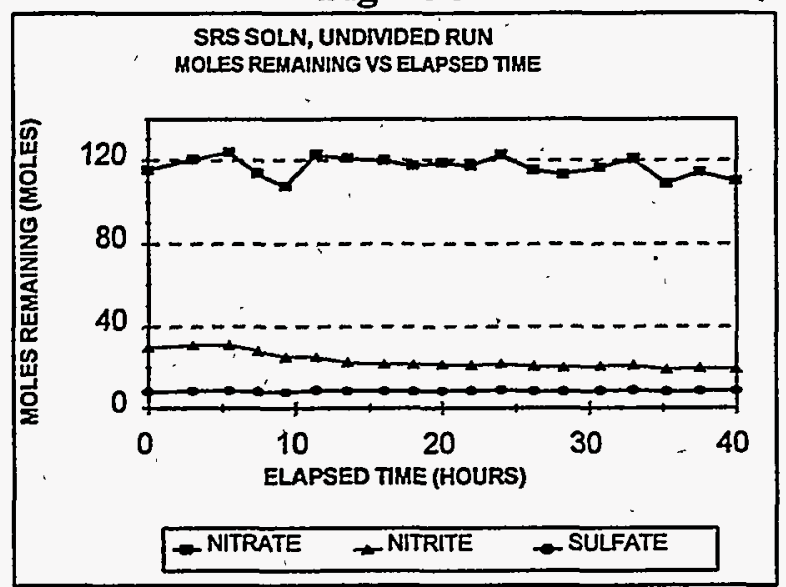

Figure 9

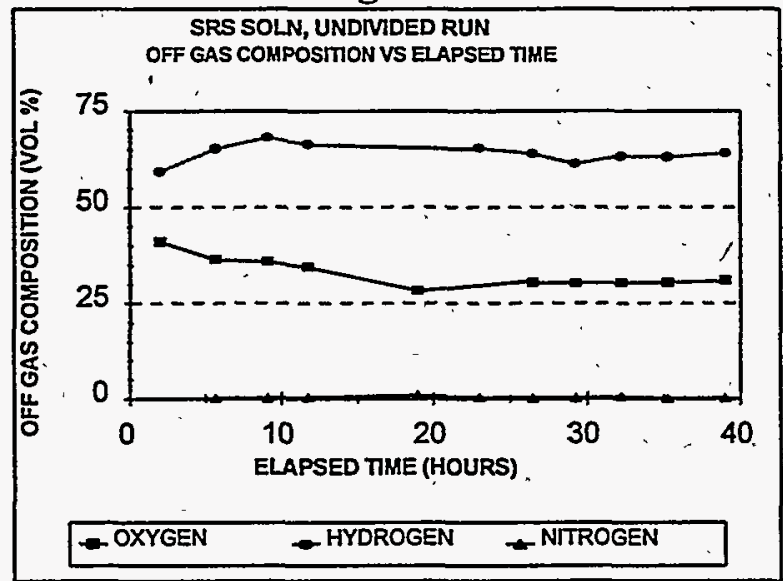

\section{Figure 10}

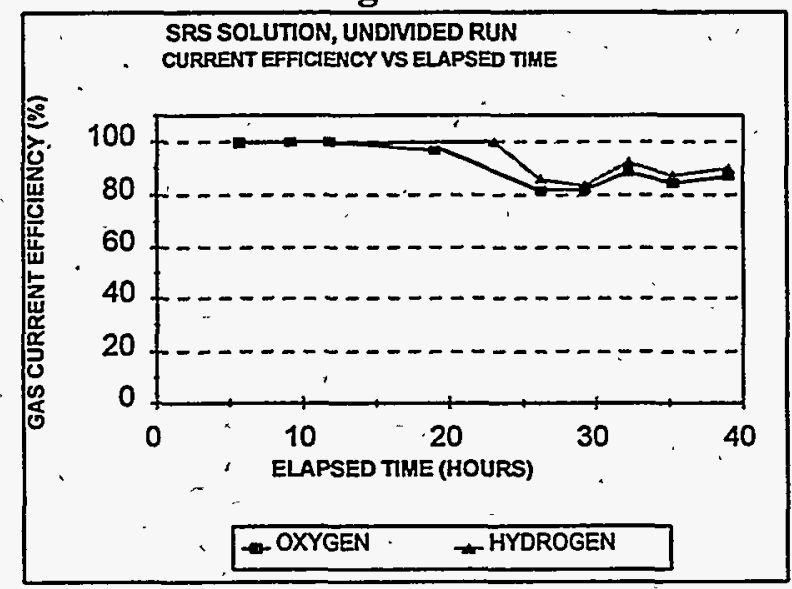

A small amount of $\mathrm{NO}_{2}{ }^{-} / \mathrm{NO}_{2}{ }^{-}$destruction was observed (11\% overall) during the run. The $\mathrm{NO}_{2}^{-}$was reduced by $\sim 36 \%$ and the $\mathrm{NO}_{3}^{-}$was reduced by $\sim 5 \%$ with an overall current efficiency of $10 \%$, assuming ammonia as the only product. The off gas composition was almost exclusively oxygen and hydrogen, with their respective current efficiencies being close to $100 \%$ during the first 
$\sim 20$ hours. Thereafter, a small drop in $\mathrm{O}_{2}$ and $\mathrm{H}_{2}$ current efficiency (down to $~ 90 \%$ ) was observed for the rest of the run. Based on the net change in moles of nitrate and nitrite and the total charge passed, the rate of destruction was calculated to be $1.5 \times 10^{-7} \mathrm{moles} /$ coulomb. $\mathrm{NO}_{2}{ }^{-}-\mathrm{NO}_{3}^{-}$gaseous reduction products were only detected in only trace amounts.

The destruction of $\mathrm{NO}_{2}{ }^{-} / \mathrm{NO}_{3}{ }^{-}$in the undivided cell is considerably less than was observed in the divided cell mode. Nitrite formed by the reduction of nitrate at the cathode could be reoxidized at the anode. This "shuttle" would result in no net change in $\mathrm{NO}_{2}{ }^{-} / \mathrm{NO}_{3}^{-}$species. The destruction rate is also less than was observed in similar undivided cell configuration tests using the FM01 cell with nickel electrodes and actual radioactive ETF solution ${ }^{19}$. Chromate was not present in the ETF solution. It is believed that the presence of chrome(VI) in the electrolyte hindered the destruction of $\mathrm{NO}_{2}^{-}-\mathrm{NO}_{3}{ }^{-}$by being reduced to chrome(III) and subsequently being deposited as an insoluble chromium(III) hydroxide layer on the cathode surface, as has been discussed previously. Due to the undivided configuration, no significant increase in caustic concentration was observed $([\mathrm{NaOH}]$ increased from $1.9 \mathrm{M}$ to $2.3 \mathrm{M})$. Therefore it is possible that if an insoluble layer of chrome(III) hydroxide had formed, that it may not have redissolved. It has been reported that chrome(III) hydroxide readily dissolves in concentrated alkalis to form chromites. ${ }^{20}$ Clearly, the chemistry of the formation and possible dissolution of the chrome (III) films is very complex and not well understood.

Initial SRS solution TOC analyses by Galbraith Laboratories (see Appendix A) are inconsistent; values of 1169,1890 and $3224 \mathrm{mg} / \mathrm{L}$ were obtained. The theory TOC for the SRS mix is $750 \mathrm{mg} / \mathrm{L}$. The error in the initial TOC analysis is probably due to the non-homogeneity of the solution. The TOC analyses at 20 hours and 40 hours are 478 and $460 \mathrm{mg} / \mathrm{L}$, respectively. These analyses may indicate some loss in TOC content, indicating that the portion of the oxidation current not being used for $\mathrm{O}_{2}$ production was shared between the reoxidation of $\mathrm{NO}_{2}^{-}$to $\mathrm{NO}_{3}{ }^{-}$and the

${ }^{19}$ D.T. Hobbs, Report No. WSRC-TR-95-0176, April 26, 1995. op. cit.

${ }^{20}$ F.A.Cotton, G. Wilkinson, P.L. Galus, "Basic Inorganic Chemistry", 2nd ed., 486 (1987). 
oxidation of organics present. The reduction portion of the "shuttle" may have been larger than the oxidation part, resulting in the net loss of $\mathrm{NO}_{2}^{-}$species observed. 'Alternatively, the cathode may not have been active for nitrate/nitrite reduction at all, and therefore the net loss of $\mathrm{NO}_{2}^{-}$would be due to oxidation of nitrite at the anode. The cell was opened up after the run and the components inspected for signs of deterioration. Photographs of cell components are included in Appendix B. The cathode appeared very clean with no visible coating apparent. The anode appeared clean except for a small area on the right lower section of the electrode which appeared to have a very fine brownish coating.

\subsection{Hanford Run 1 - Undivided Cell}

The cell was assembled using a platinized titanium anode and a nickel cathode. The nickel cathode was cleaned using emery paper followed by rinsing with water prior to being installed in the cell. The cell was run for a total of 40.16 hours over a 5 day period. The cell temperature could not be maintained at $65^{\circ} \mathrm{C}$ and rose during the day into the $70^{\circ}-80^{\circ} \mathrm{C}$ range. This temperature rise was due to the unexpectedly high cell voltage observed. The cell voltage rose from $4.4 \mathrm{~V}$ to $6.7 \mathrm{~V}$ during the first 9 hours of the run and thereafter remained relatively constant in the $6.6-7.0$ range for the rest of the run whereas the cell voltage for the SRS undivided run was $3.3-3.4$ volts and steady. Deionized water was added periodically to the tank to maintain a constant volume. The solution color changed during the run going from a dirty green color to a bright yellow. Again, there was no significant loss of caustic through the venting system (based on $\mathrm{pH}$ testing of the condensate trap). Figures 11-13 show the $\mathrm{NO}_{2}^{-} \mathrm{NO}_{3}^{-}$destruction, off gas composition, and gas current efficiencies. All of the nitrite present in the solution disappeared after $\sim 10$ hours of electrolysis. During the same time frame, the nitrate increased and then levelled off for the rest of the run. Analysis of the off gases during the run showed that they consisted exclusively of $\mathrm{O}_{2}$ and $\mathrm{H}_{2}$ with no $\mathrm{NO}_{2}^{-}-\mathrm{NO}_{3}^{-}$ reduction gas products detected. These results indicate that all the nitrite species have been oxidized to nitrate. 
Figure 11

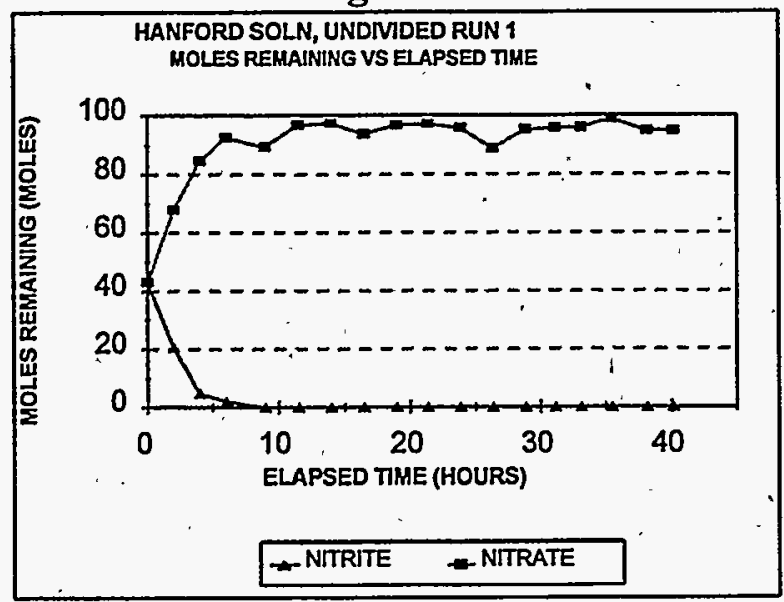

Figure 12

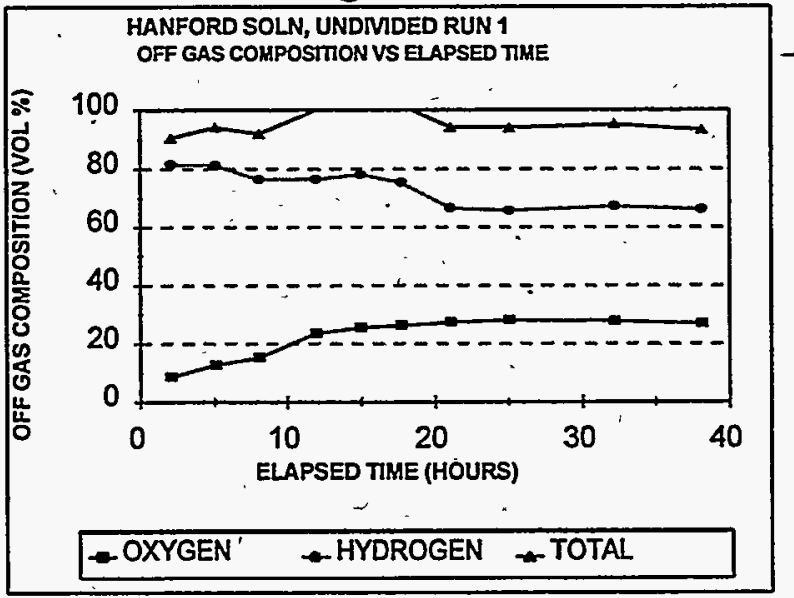

Figure 13

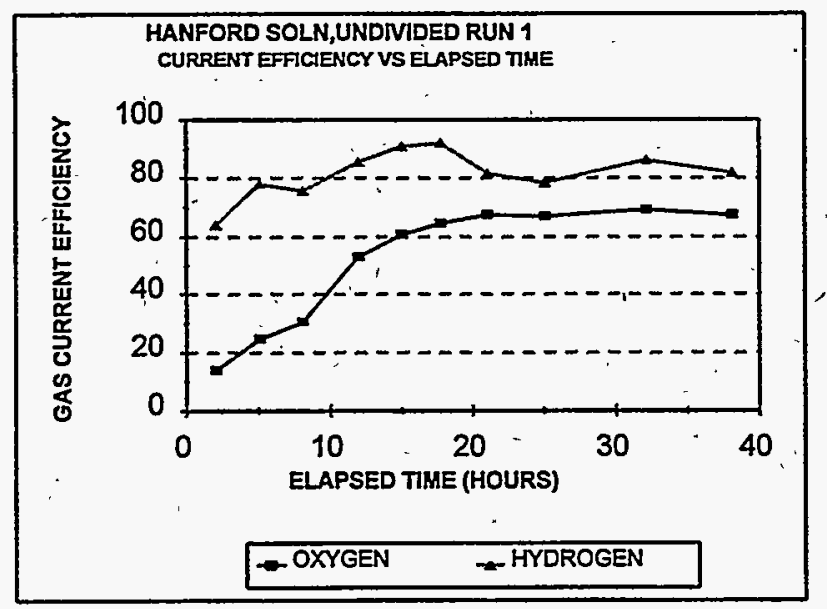

It appears that the oxidation of nitrite species to nitrate at the platinized titanium anode is occurring at a faster rate than the reduction of nitrate species to nitrite at the nickel cathode. This phenomenon has been reported previously. ${ }^{21}$ The current efficiency for hydrogen and oxygen production are both less than $100 \%$ and this is likely due to the $\mathrm{NO}_{2}^{-} \mathrm{NO}_{3}{ }^{-1}$ "shuttle" occurring. The oxygen current efficiency starts off much lower than does the hydrogen current efficiency but then both stabilize with the oxygen current efficiency at a level somewhat lower than that for hydrogen. This is consistent with a net oxidation of $\mathrm{NO}_{2}^{-}$to $\mathrm{NO}_{3}^{-}$in the first part of the run. It also indicates

${ }^{21}$ D.T. Hobbs, Report No. WSRC-TR-95-0176, April 26, 1995. op. cit. 
that another oxidation reaction (organics destruction) is occurring.

Figure 14 shows the destruction of organics during the run. There is a net destruction of $77 \%$ of the organics for the run. It also illustrates that the majority of the destruction occurs within the first 5 - 10 hours with only a minor amount of further destruction occurring for the rest of the run. The overall current efficiency for organics destruction (assuming a 40 electron process) also drops dramatically as the run progresses from a high of $60 \%$ down to less than $10 \%$ by the end of the run. The higher current efficiency observed at the start of the run may be due to the initial concentration of organics being higher thus facilitating better mass transport. Additionally, the initial organic species may be more easily oxidized, but as the run progresses, species that are harder to oxidize such as acetates and citrates ${ }^{20}$, build up. It is difficult to determine whether the presence of $\mathrm{NO}_{2}^{-}$ species had any effect on the destruction rate of organics since they both showed a dramatic decline within the first 5 hours of the run:

Figure 14

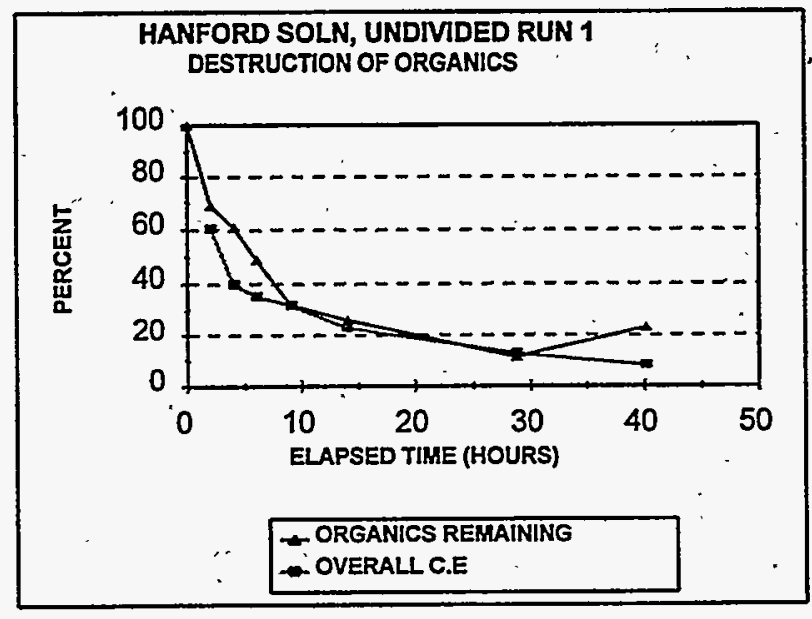

The cell was opened up for inspection and photographs (see Appendix B) of the components were taken. The anode appeared quite clean with no visible coating observed. The cathode appeared to have a very fine neutral colored coating which scraped off with a plastic scraper but was not substantial enough to collect a sample. 


\subsection{Hanford Run - Divided Cell}

The FM21 cell was assembled using the platinized titanium anode which had been wiped with tissue and rinsed with water, a nickel cathode which was cleaned with emery paper and then rinsed with water, and the Nafion 350 membrane from the SRS simulant divided cell run. This membrane had been stored in deionized water. The catholyte consisted of 30 gal of regular Hanford simulant and the anolyte consisted of 40 gal of depleted Hanford simulant (described previously). In order to make up this simulant it was assumed that all sodium nitrite and sodium nitrate species had been reduced via the six or eight electron process described previously to the hydroxide species, hence the simulant had a nominal starting alkalinity of $\sim 13 \mathrm{M} \mathrm{NaOH}$.

Upon starting up the cell, it was immediately noticed that a very high cell voltage $(8 \mathrm{~V})$ was obtained at very low currents $\left(0.66 \mathrm{kA} / \mathrm{m}^{2}\right)$. Electrode potentials did not appear excessive with the anode being $0.4 \mathrm{~V}$ vs $\mathrm{SCE}$ and the cathode $1.9 \mathrm{~V}$ vs $\mathrm{SCE}$. Solution conductivities appeared normal

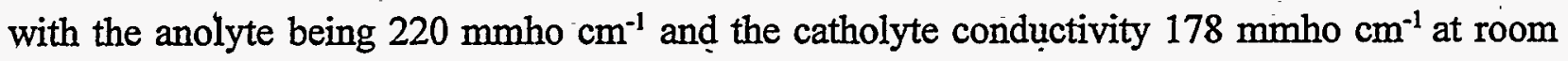
temperature. At $0.66 \mathrm{kA} / \mathrm{m}^{2}$, the combined solution $\mathrm{i} R$ loss at room temperature would only be 340 $\mathrm{mV}$ given that the membrane to electrode gap in the FM21 Cell is $0.5 \mathrm{~cm}$. The voltage problem was remedied by replacing the membrane with a new piece pretreated by soaking in $1 \mathrm{M} \mathrm{NaOH}$ at $90^{\circ} \mathrm{C}$ for $\sim 2-1 / 2$ hours. The cell was run for a total of 38.2 hours. Solution temperatures fluctuated between $65-75^{\circ} \mathrm{C}$ for most of the run. The catholyte and anolyte solution volumes were maintained relatively constant by the periodic addition of deionized water to both sides. The run was stopped before the 40 hour mark because of rapidly increasing cell voltages and temperature. Much dense foam was observed in the catholyte reservoir at the end (approx. $80 \%$ of the total volume) which was attributed to an oversaturation of the catholyte with transported sodium ions resulting in precipitation of solids in the form of foam.

Figures $15-18$ show the destruction of $\mathrm{NO}_{2}^{-}-\mathrm{NO}_{3}^{-}$species, off gas composition, gas production rate, and the hydrogen current efficiency occurring during this run. There was a $60.8 \%$. destruction of nitrite species and a $47.9 \%$ destruction of nitrate species for an overall total of $54.2 \%$ 
destruction. The overall current efficiency was $51 \%$, assuming ammonia to be the only product. The catholyte off gas composition consisted almost exclusively of hydrogen with small amounts of ammonia detected: $\mathrm{No} \mathrm{N}_{2} \mathrm{O}$ or $\mathrm{N}_{2}$ was detected. It is likely that the small amounts of ammonia detected are due to poor degassing at the sample point. Gas samples were taken exiting the catholyte circulation tank in an effort to more accurately detect/quantify the gaseous reduction products. However, due to the magnitude of the dilution of the cell off gases, their concentrations were too small to be detected by GC analysis.

Figure 15

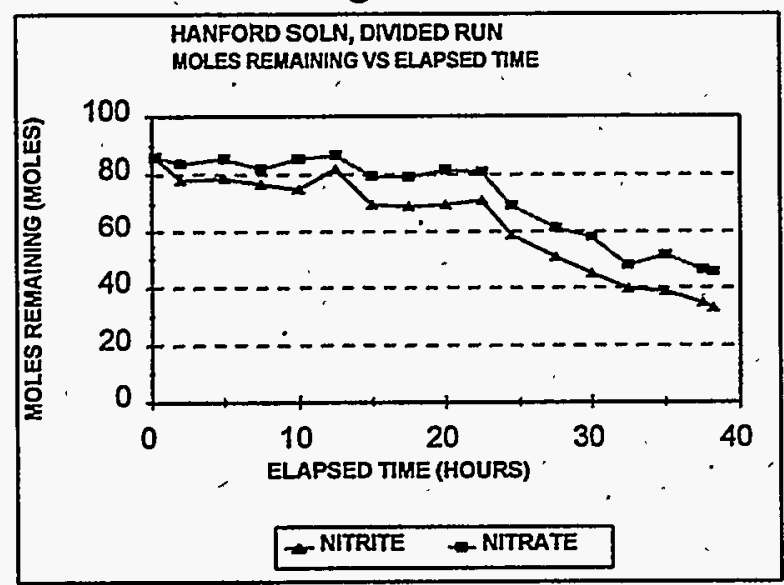

Figure 17

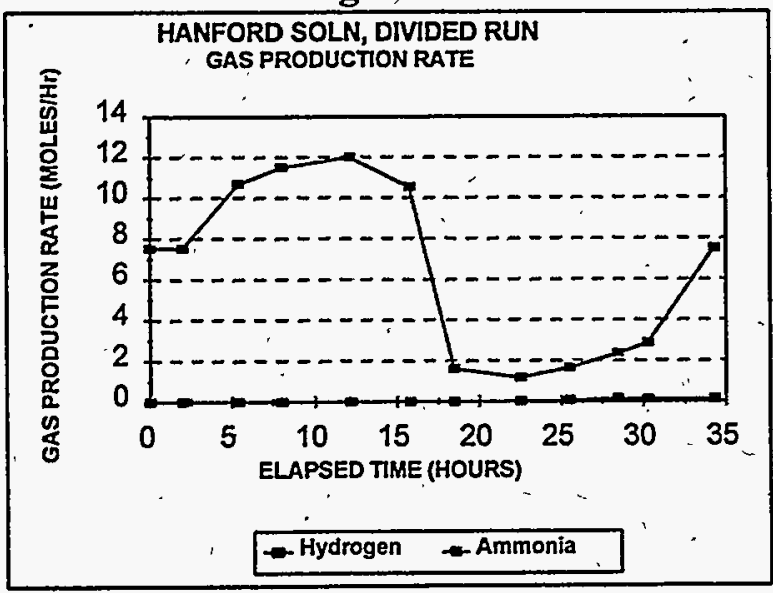

Figure 16

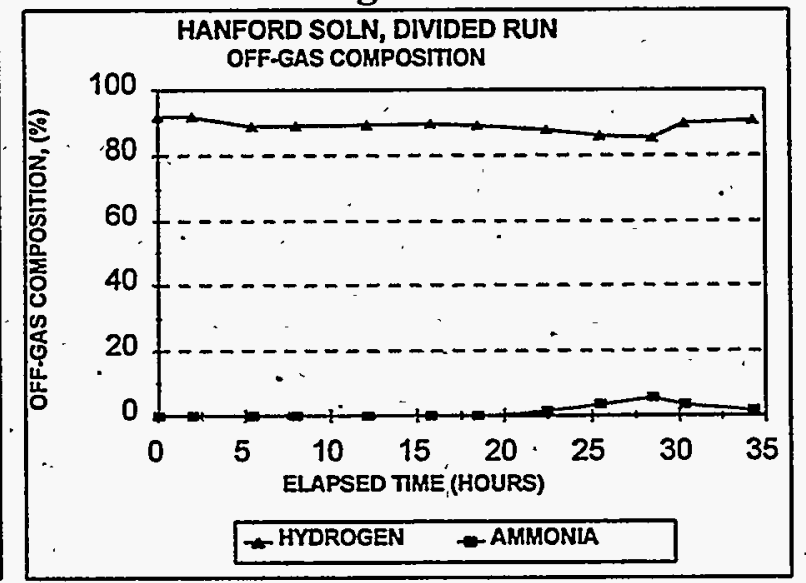

Figure 18

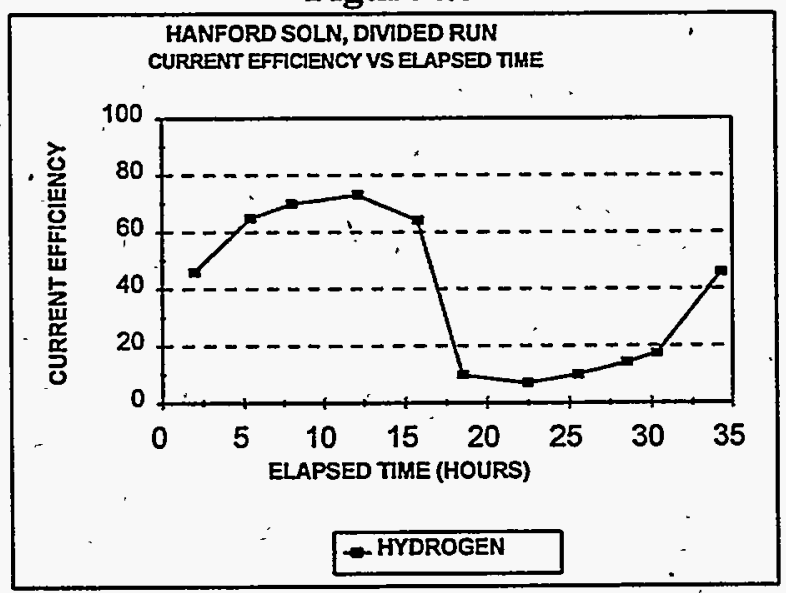

Based on the net change in moles of nitrite and nitrate and the total charge passed, the overall rate of destruction was calculated to be $7.7 \times 10^{-7} \mathrm{moles} /$ coulomb. This is low when compared to that 
previously reported for ETF solutions by WSRC'22, and reflects the "induction period " that was observed for the first approx. 22.5 hours of the run when very little reduction occurred. When this calculation is done based on the change occurring after the "induction period", then the rate of destruction is $1.48 \times 10^{-6}$ moles/coulomb, which closely matches those obtained by WSRC. This "induction period" was also observed in the SRS simulant divided run. It is possible that chrome(III) hydroxide may have adsorbed onto the cathode, shutting down the reduction process until the alkalinity had increased enough to redissolve the adsorbed layer. The rate of destruction of $\mathrm{NO}_{2}^{-}$ NO3- species in this run is significantly different than was observed in the undivided cell configuration using the Hanford simulant. This is due primarily to the membrane preventing the migration of oxidized or reduced species to the other electrode to be reduced or oxidized back to their original state. Overall 211 moles of hydrogen were produced and 46 moles of nitrite plus 35.8 moles of nitrate were consumed up to the 34.8 hour mark of the run (the last gas sample taken). If we assume ammonia to be the only reduction product, then the hydrogen and ammonia formation would require 985 moles of electrons, which is approx. $87 \%$ of the 1129 moles of electrons passed over 34.3 hours. It is possible that the large amounts of foam observed further contributed to the poor degassing of solution at the sample point, making accurate quantitative gas analysis difficult.

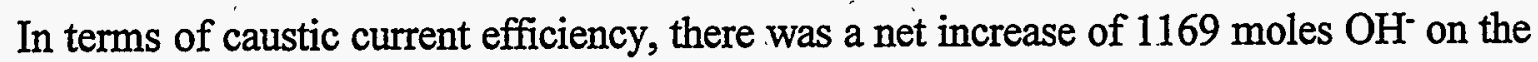
cathode side. If we assume the total theoretical caustic increase was 361.9 moles (via $\mathrm{NO}_{2}^{-}$ reduction) +377.1 moles (via $\mathrm{NO}_{3}^{-}$reduction) +611 moles (charge remaining from total) equalling 1350 moles, then the caustic current efficiency was $87 \%$, which is not uncommon for $\mathrm{Nafion}^{\mathrm{R}} 300$ series membranes in chlor-alkali applications. ${ }^{23}$ When the current efficiency is calculated for the anolyte side based on change in alkalinity (including carbonate formed) the current efficiency is $78 \%$.

Figure 19 shows the concentration of organics (as analyzed by Gälbraith laboratories) during

\footnotetext{
${ }^{22}$ D.T. Hobbs, Report No. WSŔC-TR-95-0176, April 26, 1995. op. cit.

${ }^{23}$ M.O.Coulter, "Modern Chlor-Alkali Technology", Vol. 1, 174 (1980).
} 
the run. There is some uncertainty in the results, particularly the initial sample, due to the nonhomogeneous nature of the sample. The high alkalinity/sodium content of the starting solution may have rendered the organic salts partially insoluble, accounting for the lower than expected TOC content. As the run progressed, sodium was transported across the membrane and alkalinity decreased, thus allowing more organics into solution. The final TOC content equates to a net destruction of approx. 22\% (assuming the starting concentration to be the theoretical amount which was added). This is lower than was observed in the undivided run and again is likely related to the lower solubility.

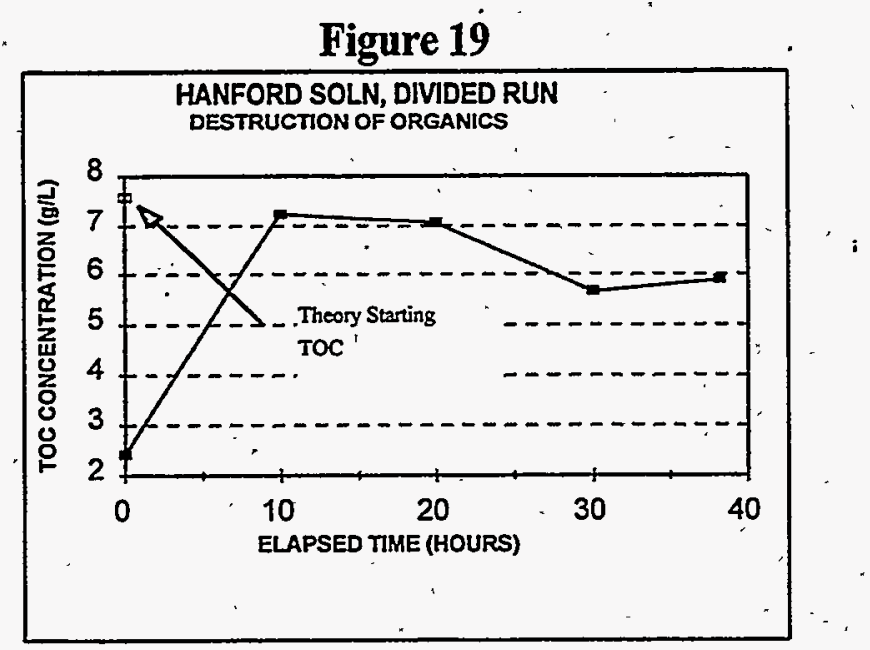

The cell was opened up for inspection and photographs taken (Appendix B). The anode appeared clean except for slight discolorations over some areas of the electrode. The cathode had a black deposit over almost the entire surface of the electrode which was not easily removed by wiping. The membrane appeared stained with brown deposits along the bottom right surface on the anode side. 


\section{Conclusions and Recommendations}

The Electrosynthesis Company has successfully demonstrated the operation of the ICI FM21-SP commercial scale electrochemical flow cell for the removal of nitrite, nitrate and organic species from SRS and Hanford waste simulants. The cell was operated in both divided and undivided configurations for at least 40 hours per experiment or until $50 \%$ of the nitrites, nitrates, and organics were destroyed. Current efficiencies and destruction rates were determined for organics and nitrite/nitrate species.

The results obtained with the ICI FM21-SP cell for $\mathrm{NO}_{2}{ }^{-} \mathrm{NO}_{3}{ }^{-}$destruction in the divided cell configuration are similar to those obtained previously at ESC as well as to those obtained at WSRC (Table 5). The presence of chrome (VI) species in SRS simulant appears to be harmful to the reduction reaction in both the divided and undivided configurations where a nickel cathode is used. In the divided configuration an "induction period"is seen where very little reduction takes place. Once this period is over the reaction then proceeds at a rate similar to the reduction rate in the ETF solution where no chrome is present. The reduction rate seen in the present work after the induction period is also similar to the Phase II laboratory scale work with a nickel cathode at ESC.

In the undivided configuration with the SRS mix no net reduction of nitrite/nitrate was seen. The postulated formation of chrome (III) hydroxide film on the cathode may combine with the "shuttle" effect to stop the net reduction of $\mathrm{NO}_{2}^{-}-\mathrm{NO}_{3}^{-}$species for the entire run. When the Hanford simulant was used in the undivided cell, the platinised titanium anode proved to be more efficient at oxidizing $\mathrm{NO}_{2}^{-}$to $\mathrm{NO}_{3}^{-}$than the nickel cathode was at the reduction process $\left(\mathrm{Cr}^{3+}\right.$ present), thus no net reduction of species was observed throughout the run. In the divided configuration an "induction period" was also seen after which the destruction rate was similar to that seen for SRS simulant. Further work needs to be done to more completely understand the chemistry and the effects of the chrome species on the reduction reactions occurring at the cathode.

The destruction of organics in the SRS undivided cell run was difficult to quantify due to uncertainty in the analysis. In the Hanford simulant undivided run, much higher organics destruction was observed than in the divided cell run. The reason for the difference likely lies in the difference 


\section{The Electrosynthesis Co., Inc.}

Page 33

in solubility of the organic species in the solutions. The anolyte in the divided run contained much more $\mathrm{Na}^{+} / a l k a l i n i t y$, thus reducing the solubility and hence the reaction rate. The destruction of organics. in Hanford solution should be further investigated as a function of $\mathrm{Na}^{+} /$alkalinity.

Finally, in light of the fact that a possible membrane failure occurred at the end of the SRS divided run, membrane stability studies should be conducted in both SRS and Hanford solutions.

\section{Table 5}

\begin{tabular}{|l|c|c|c|}
\hline \multicolumn{1}{|c|}{ Run } & $\begin{array}{c}\text { Overall } \mathrm{NO}_{2} / \mathrm{NO}_{3}, \\
\text { Destruction Rate } \\
\text { (Moles/Coulomb) }\end{array}$ & $\begin{array}{c}\mathrm{NO}_{2} / \mathrm{NO}_{3} \text { Destruction Rate } \\
\text { After Induction Period } \\
\text { (Moles/Coulomb) }\end{array}$ & $\begin{array}{c}\text { Organics } \\
\text { Destruction } \\
(\%)\end{array}$ \\
\hline SRS, Divided Cell & $7.9 \mathrm{E}-7$ & $1.26 \mathrm{E}-6$ & - \\
\hline SRS, Úndivided Cell & $1.5 \mathrm{E}-7$ & $1.5 \mathrm{E}-7$ & - \\
\hline Hanford, Undivided & 0 & 0 & 77 \\
\hline Hanford, Divided & $7.7 \mathrm{E}-7$ & $1.48 \mathrm{E}-6$ & 22 \\
\hline $\begin{array}{l}\text { ESC Phase 2, Divided } \\
\text { (Run 223-51) }\end{array}$ & $8.9 \mathrm{E}-7$ & $1.0 \mathrm{E}-6$ & - \\
\hline $\begin{array}{l}\text { WSRC, Divided ETF } \\
\text { (Runs ED11-ED15) }\end{array}$ & $1.1-1.5 \mathrm{E}-6$ & $1.1-1.5 \mathrm{E}-6$ & - \\
\hline PNL & - & - & 50 \\
\hline
\end{tabular}


The Electrosynthesis Co., Inc.

\subsection{Appendix A: TOC Analyses}


Summary Identification Of Samples Analysed By Galbraith Laboratories.

\begin{tabular}{|c|c|c|}
\hline Their Sample ID \# & Run & Elapsed Time (Hours) \\
\hline L 7721 & Initial SRS Soln & ----.-- \\
\hline L 7722 & SRS Undivided & 40 \\
\hline L 7723 & SRS Undivided & 20 \\
\hline L 7724 & SRS Divided (Catholyte) & .49 .3 \\
\hline L 7725 & SRS Divided (Catholyte) & 25.2 \\
\hline L 7726 & SRS Divided (Catholyte) & 41.1 \\
\hline M 0700 & Initial SRS Soln (Repeat) & 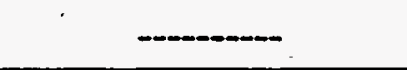 \\
\hline L 9420 & $\begin{array}{l}\text { Initial Hanford Soln } \\
\text { (Undivided Run) }\end{array}$ & - \\
\hline L 9421 & Hanford Undivided & 14 \\
\hline L $9422^{\circ}$ & Hanford Undivided & 28.8 \\
\hline L 9423 & Hanford Undivided & 40.2 \\
\hline M 2793 & Hanford Undivided & 2.1 \\
\hline M 2794 & Hanford Undivided. & 4.1 \\
\hline M 2795 & Hanford Undivided & 6.1 \\
\hline M 2796 & Hanford Undivided & 9 \\
\hline M 4057 & $\begin{array}{l}\text { Initial Hanford Soln } \\
\text { (Divided Run, Anolyte) }\end{array}$ & - \\
\hline M 4058 & Hanford Divided, Anolyte & 10 \\
\hline M 4059 & Hanford Divided, Anolyte & 20 \\
\hline M 4060 & Hanford Divided, Anolyte & 30 \\
\hline M 4061 & Hanford Divided, Anolyte & 38.2 \\
\hline M-5480 & Repeat of M- 4057 & -...-...- \\
\hline M-5481 & Repeat of M-4058 & 10 \\
\hline M-5482 & Repeat of M-4059 & 20 \\
\hline M-5483 & . Repeat of M-4060 & 30 \\
\hline M-5484 & Repeat of M-4061 & 38.2 \\
\hline
\end{tabular}




\section{LABORATORY REPORT}

\section{AMENDED}

Dennis Chai.

The Electrosynthesis Co 72 Ward Road Lancaster NY 14086
Sample Received:

Report Date:

Purchase .Order \#:
$07 / 10 / 95$

$08 / 11 / 95$

WSRC370695DC

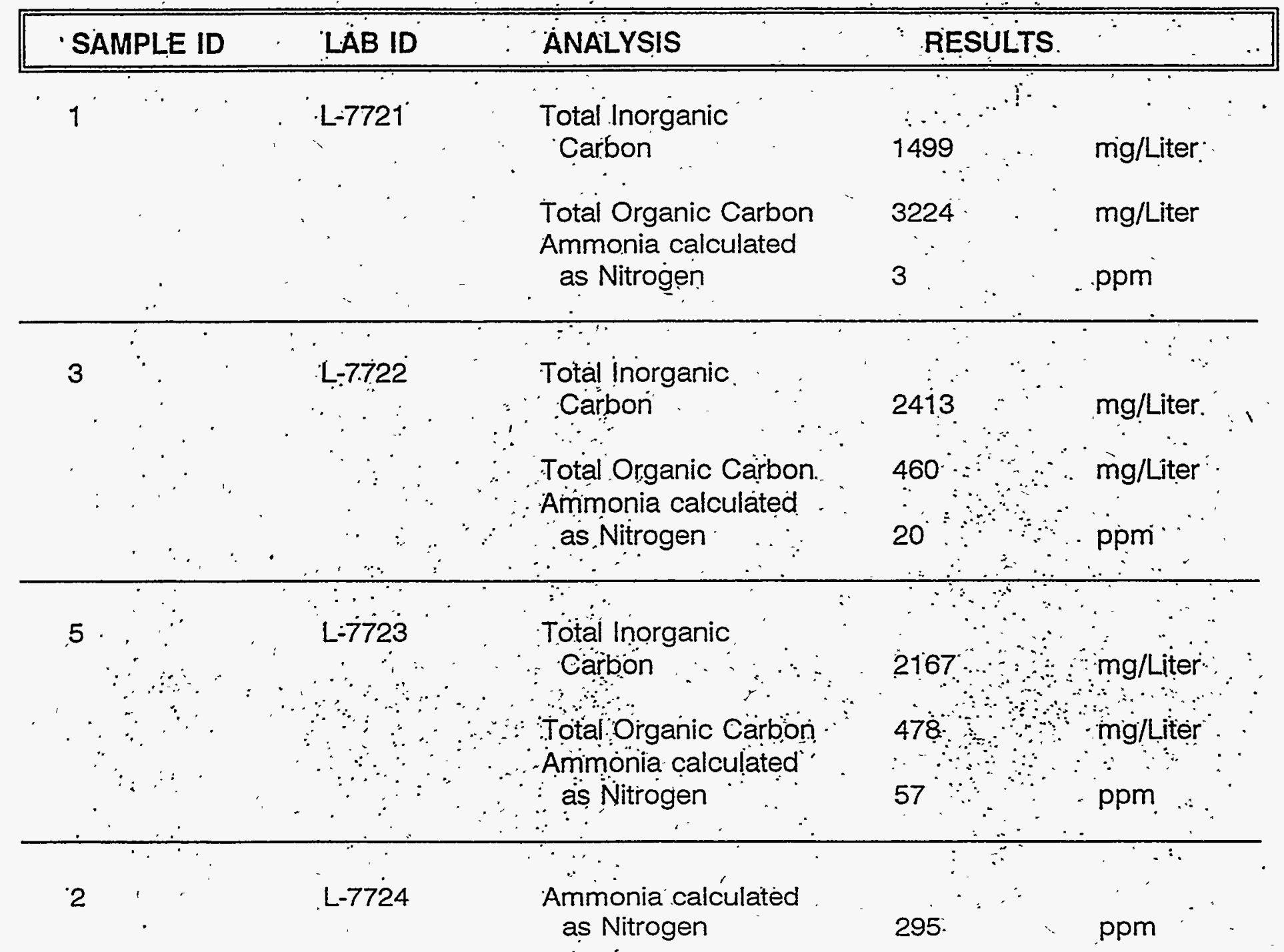

Page 1 of 2

P.O. Box 51610 . Knoxville, TN 37950-1610

Fax: (615) $546-7209$ 


\section{LABORATORY REPORT}

\section{AMENDED}

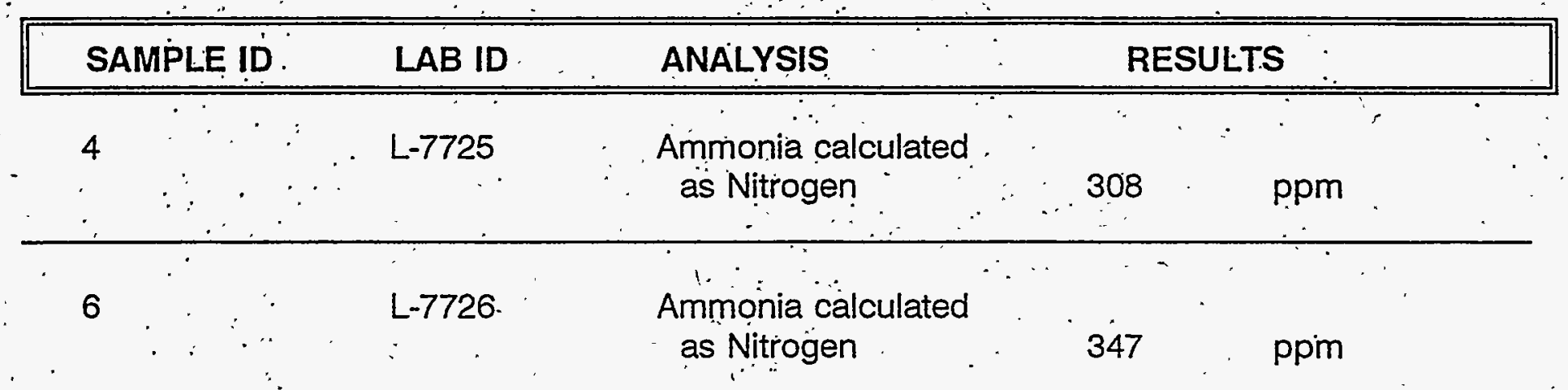

CBM:le

Page 2 of 2 


\section{LABORATORY REPORT}

Dennis Chai

The Electrosynthesis Company 72 Ward Road

Lancaster ' NY 14086
Amended Report

Reanalysîs:Request:" $\quad$ '08/02/95

Previous Lab I:D.: L-7721

Report Date:

$08 / 08 / 95$

Amended Date:

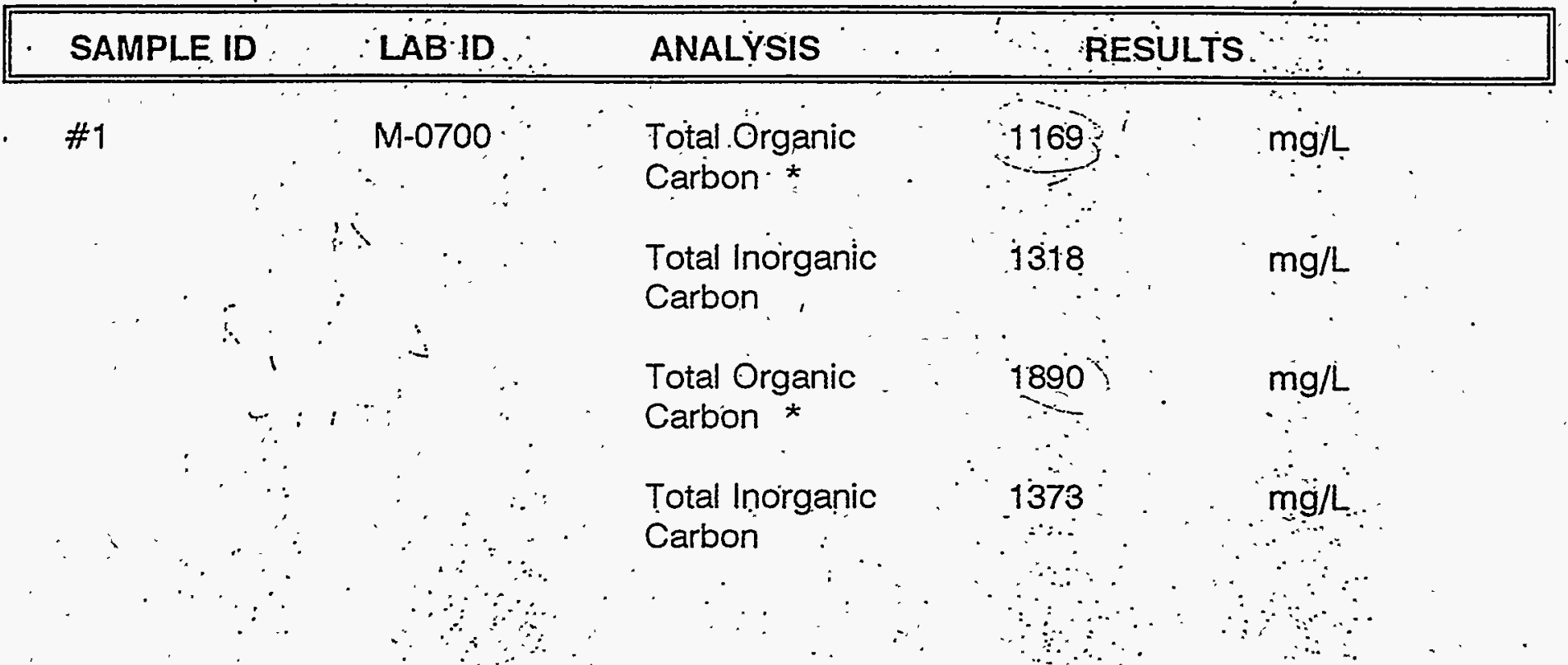

Note: * The Total Organic Carbon precision is poor in this sample due to the non-homogenous nature of this solution.

Note: There will be no charge for this repeat analysis. 


\section{LABORATORY REPORT}

Denniș Chai

The Electrosynthesis Company 72. Ward Road

Lancaster NY 14086
Sample Received:

Report Date:

Purchase. Order \#:
$07 / 21 / 95$

$08 / 01 / 95$

WSRC371895DC

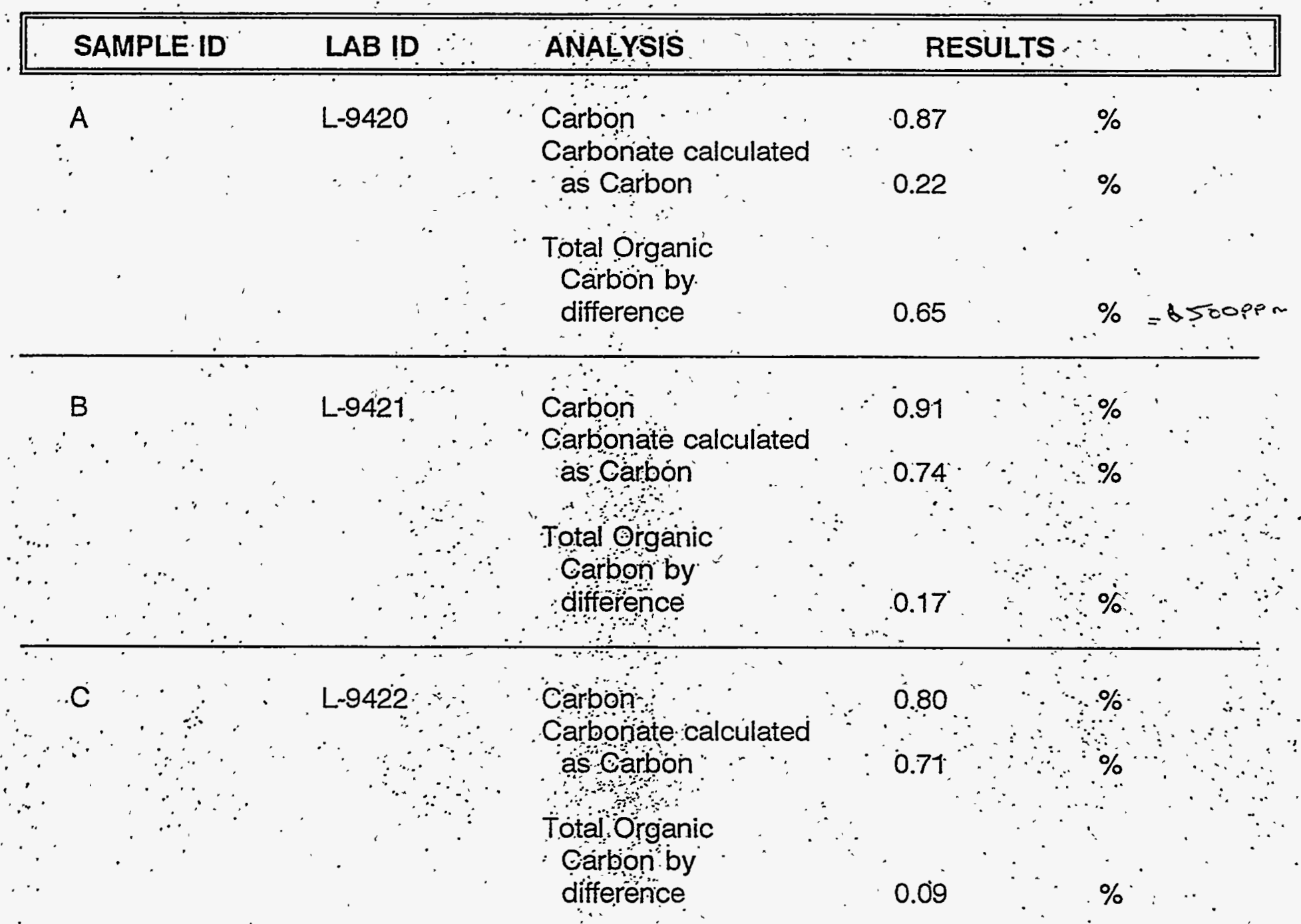

Page 1 of 2 


\section{LABORATORY REPORT}

Dennis Chai

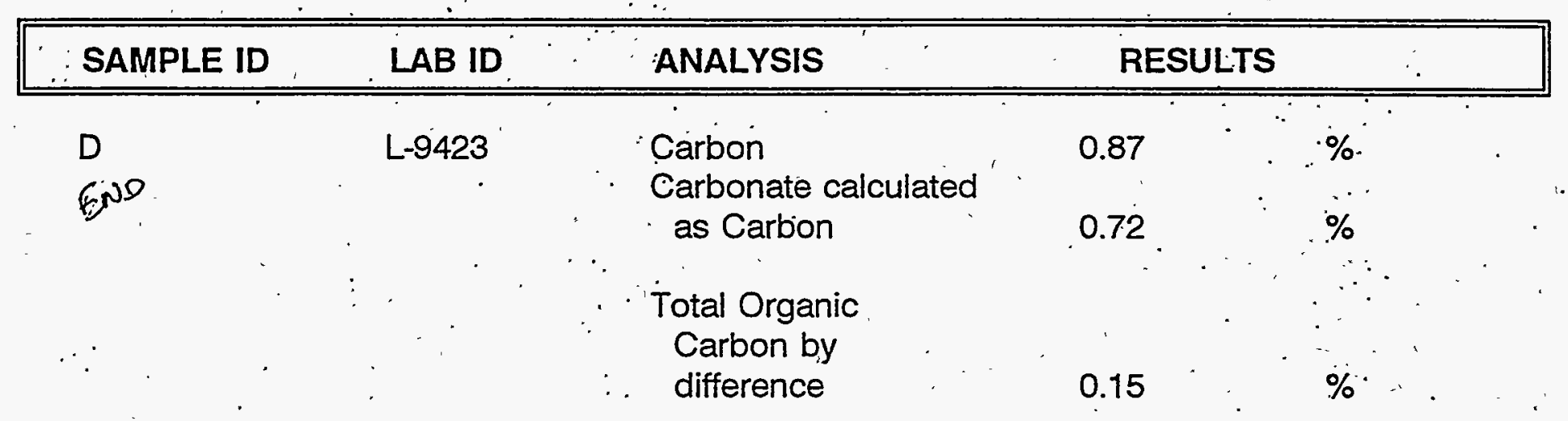

CB:le

Page 2 of 2 


\section{LABORATORY REPORT}

Dennis Chai

The Electrosynthesis Co 72 Ward Road Lancaster NY 14086
Sample Received:

Report Date:

Purchase Order \#:
$08 / 17 / 95$

$08 / 25 / 95$

WSRC381595DC2

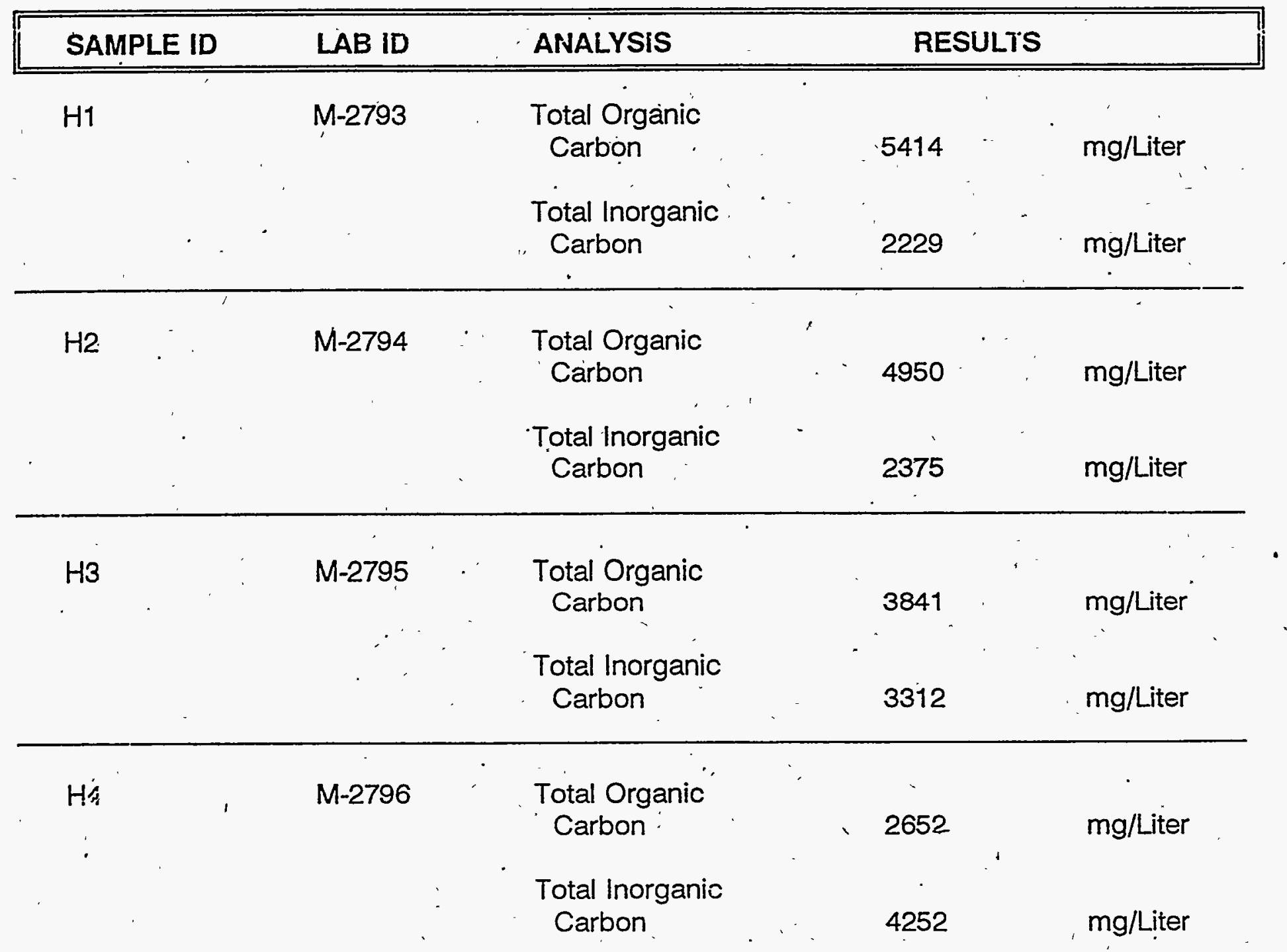

AL:le 


\section{GALBRAITH LABORATORIES, INC.}

Accuracy with speed - since 1950

\section{LABORATORY REPORT'}

Dennis Chai

The Electrosynthesis Co

72 Ward Road

Lancaster NY 14086
Sample Received: $\quad$ 08/25/95

: Report Date: ‘ 09/05/95

Purchase Order \#: . WSRC382495DC

\begin{tabular}{|ccccc|}
\hline SAMPLE ID & LAB ID & ANALYSIS & RESULT'S \\
\hline HA 1 & M-4057 & $\begin{array}{c}\text { Total Organic } \\
\text { Carbon }\end{array}$ & 2344 & mg/Liter \\
\hline HA2 & $\begin{array}{c}\text { Total Inorganic } \\
\text { Carbon }\end{array}$ & 1080 & mg/Liter \\
\hline
\end{tabular}

HA 3

M-4059 Total Organic

Carbon

6425

mg/Liter

Total' Inorganic

Carbon

5365

mg/Liter

HA 4

$M-4060$

Total Organic

Carbon

5613

$\mathrm{mg} /$ Liter

Total Inorganic

Carbon

2768

mg/Liter

Page 1 of 2 


\section{LABORATORY REPORT}

Dennis Chai

\begin{tabular}{|c|c|c|c|c|}
\hline SAMPLE ID & LAB ID & ANALYSIS & RES & \\
\hline \multirow[t]{2}{*}{ HA 5} & $M-4061$ & $\begin{array}{l}\text { Total Organic } \\
\text { Carbon }\end{array}$ & 5979 . & mg/Liter \\
\hline & . & $\begin{array}{l}\text { Total Inorganic } \\
\text { Carbon }\end{array}$ & 2347 & $\mathrm{mg} /$ Liter \\
\hline
\end{tabular}




\section{LABORATORY REPORT}

Dennis Chai

The Electrosynthiesis Co

72 Ward Road

Lancaster NY 14086
Reanalysis Request:

Previous Lab I.D.:

Report Date:
$09 / 07 / 95$

$M-4057-61$

$09 / 11 / 95$

\begin{tabular}{|c|c|c|c|c|}
\hline SAMPLE ID & LAB ID & ANALYSIS & \multicolumn{2}{|c|}{ RESULTS } \\
\hline \multirow[t]{2}{*}{ HA 1} & $M-5480$ & $\begin{array}{l}\text { Total Organic } \\
\text { Carbon }\end{array}$ & 2511 & mg/Liter \\
\hline & & $\begin{array}{l}\text { Total Inorganic } \\
\text { Carbon. }\end{array}$ & 1956 & mg/Liter \\
\hline \multirow[t]{2}{*}{ HA 2} & $M-5481$ & $\begin{array}{l}\text { Total Organic } \\
\text { Carbon }\end{array}$ & 7145 & mg/Liter \\
\hline & & $\begin{array}{l}\text { Total Inorganic } \\
\text { Carbon }\end{array}$ & 2370 & mg/Liter \\
\hline HA 3 & $M-5482$ & $\begin{array}{l}\text { Total Organic } \\
\text { Carbon }\end{array}$ & 7735 & mg/Liter \\
\hline . & & $\begin{array}{l}\text { Total Inorganic } \\
\text { Carbon }\end{array}$ & 2604 & mg/Liter \\
\hline
\end{tabular}

HA 4

$M-5483$

Total Organic

Carbon

5720

$\mathrm{mg} /$ Liter

Total Inorganic

Carbon

2790

mg/Liter 


\section{LABORATORY REPORT}

Dennis Chai

\begin{tabular}{|c|c|c|c|c|}
\hline SAMPLE ID & LAB ID & ANALYSIS & \multicolumn{2}{|c|}{ RESULTS } \\
\hline HA 5 & M-5484 & $\begin{array}{l}\text { Total Organic } \\
\text { Carbon }\end{array}$ & 5830 & mg/Liter \\
\hline & & $\begin{array}{l}\text { Total Inorganic } \\
\text { Carbon }\end{array}$ & 2134 & mg/Liter \\
\hline
\end{tabular}

Notes: Samples contain solid particles and were very difficult to mix in order to achieve a homogeneous sample for analysis.

There will be no charge for these repeat analyses.

CBM:le

Page 2 of 2 
The Electrosynthesis Co., Inc.

Page 35

\subsection{Appendix B: Cell Photographs}




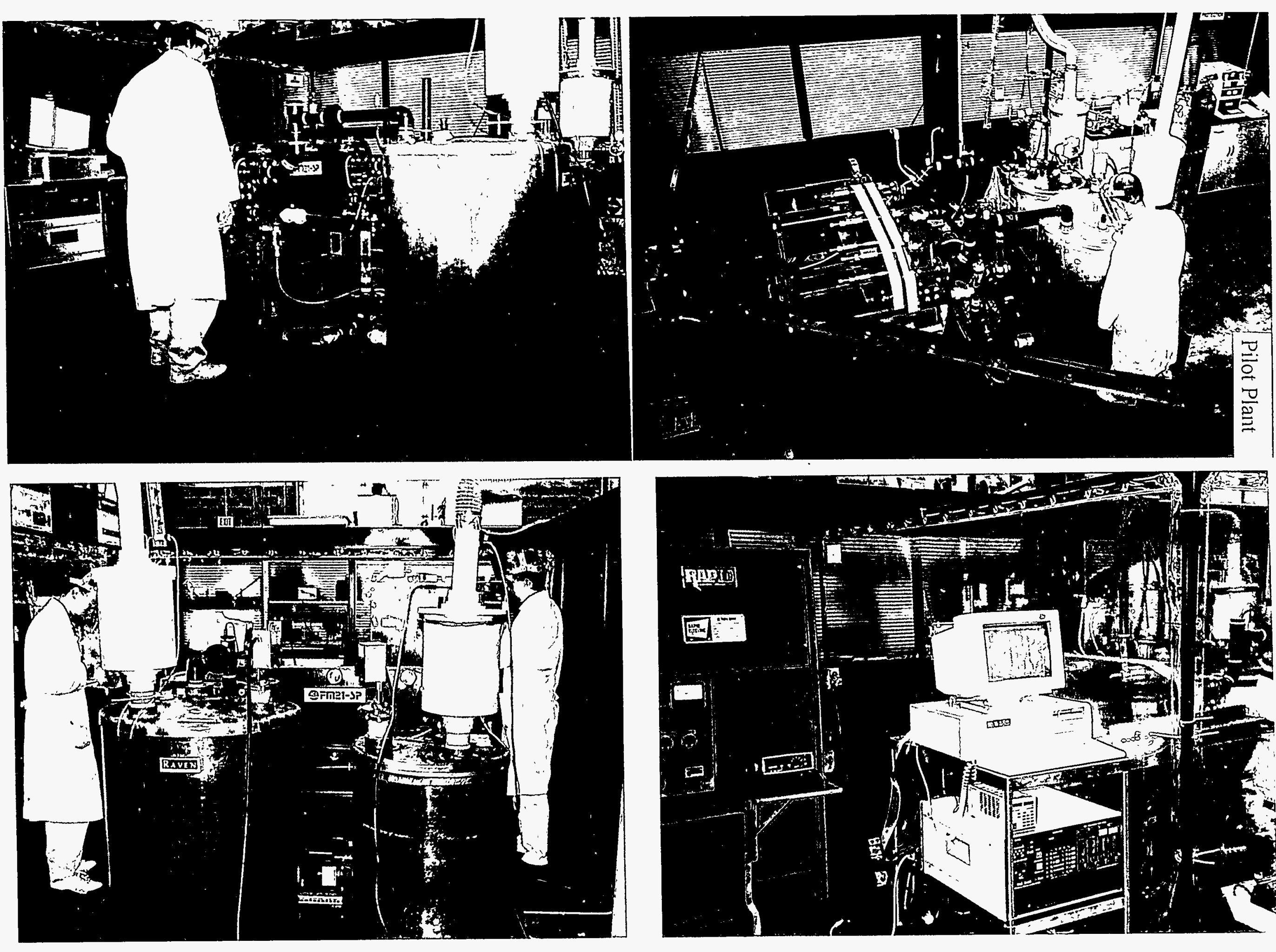




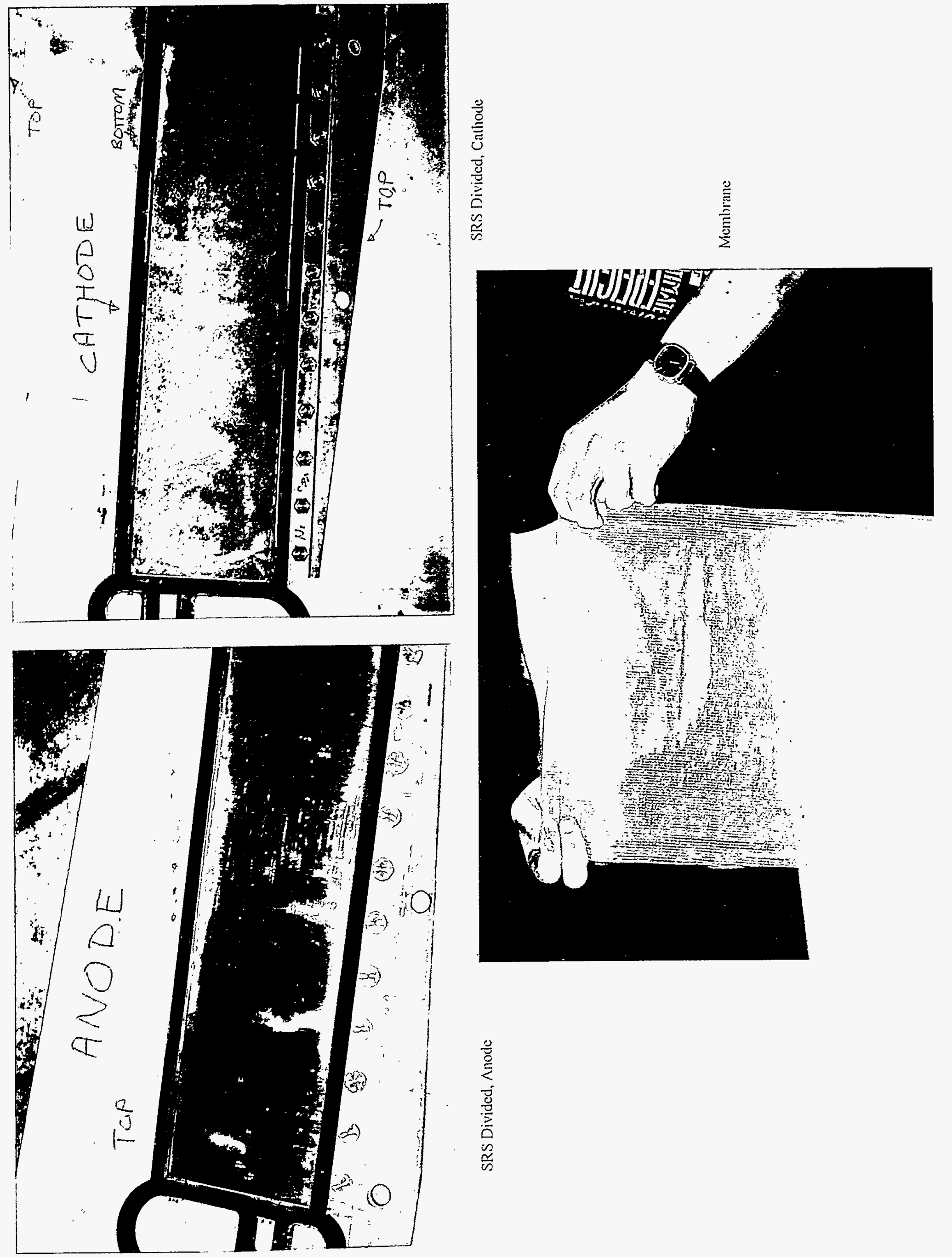



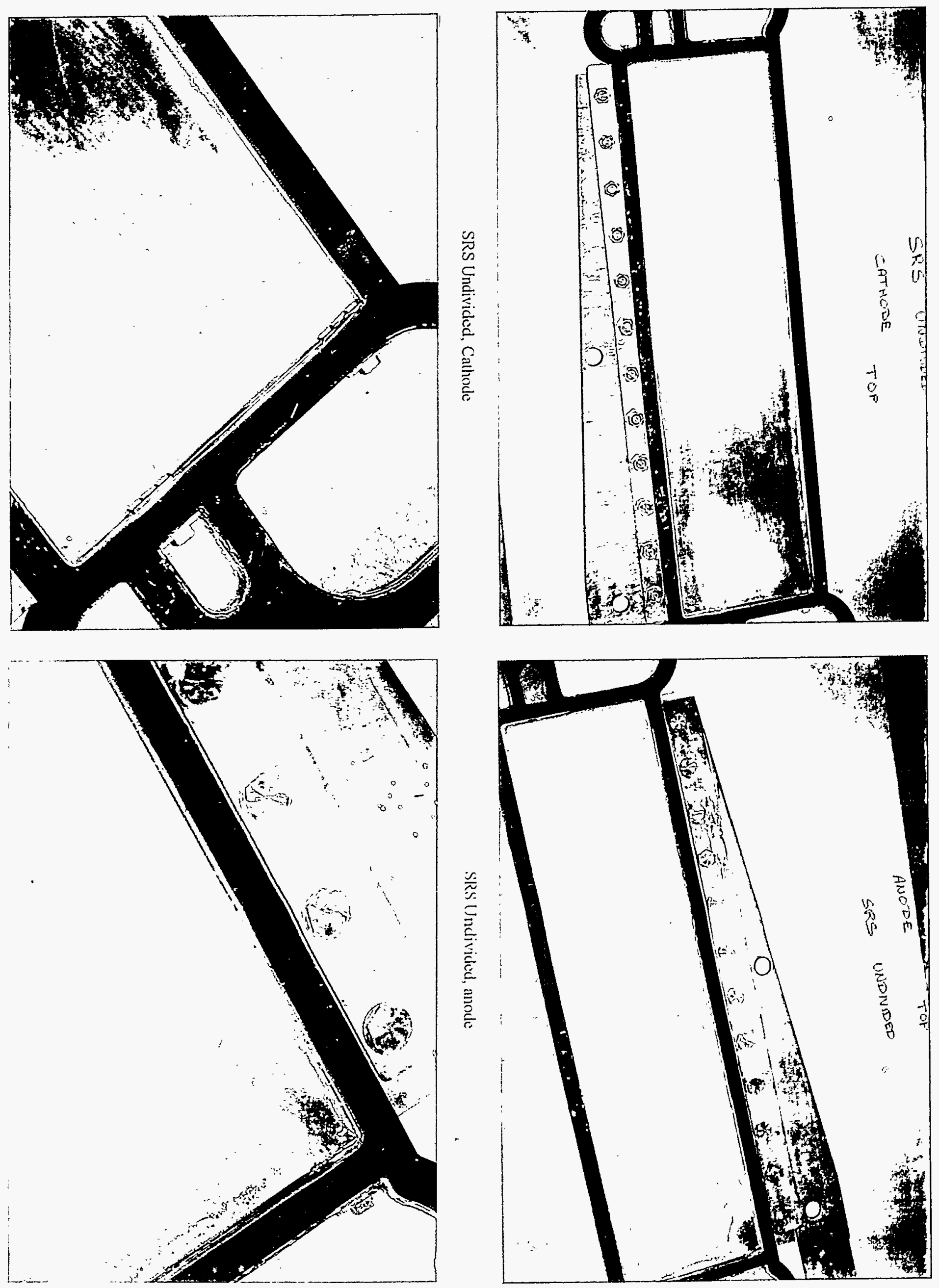

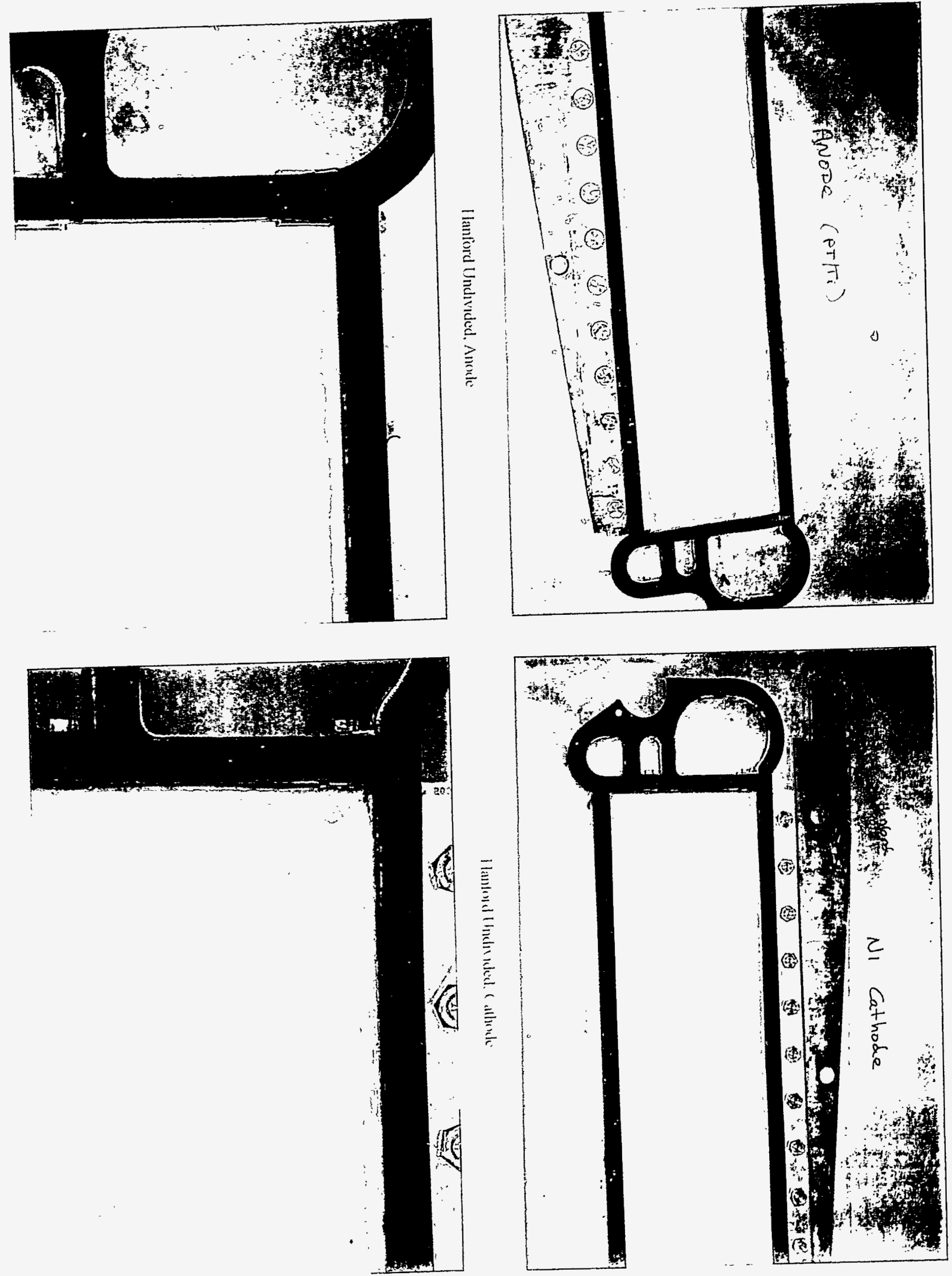

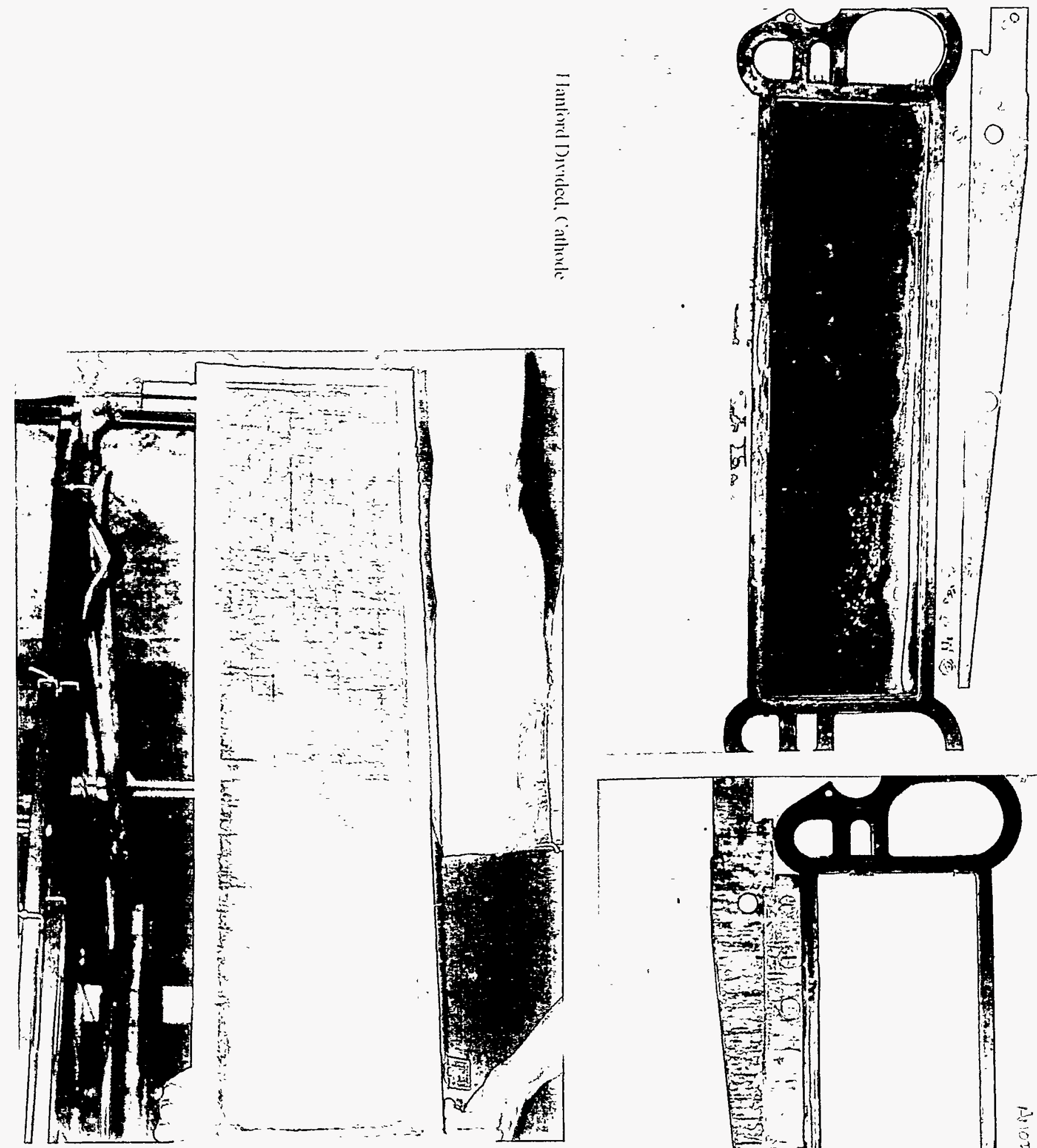

旁

言 